\title{
Various Absorbents and Parameters Affecting Removal of Water Hardness from Wastewater: Review
}

\author{
Misikir Tamiru, and Gabisa Bekele* \\ Department of Material Science and Engineering, Adama Science and Technology University, 2020 Adama, Ethiopia
}

*Corresponding author: Gabisa Bekele, Department of Material Science and Engineering, Adama Science and Technology University, 2020 Adama, Ethiopia, E-mail: gebisabek12@gmail.com

Received: 09 Oct, 2020 | Accepted: 06 Nov, 2020 | Published: 14 Nov, 2020

Citation: Tamiru M, Bekele G (2020) Various Absorbents and Parameters Affecting Removal of Water Hardness from Wastewater: Review. Int J Water Wastewater Treat 6(3): dx.doi.org/10.16966/2381-5299.173

Copyright: (C) 2020 Tamiru M, et al. This is an open-access article distributed under the terms of the Creative Commons Attribution License, which permits unrestricted use, distribution, and reproduction in any medium, provided the original author and source are credited.

\begin{abstract}
Discharges of heavy metals from different sources to the water lead to water hardness which is the major problem of the world due to their toxic and carcinogenic nature. Among several methods to eliminate heavy metals, absorption is the leading technique for the removal of heavy metals from wastewater because it is efficient, available, low-cost, and eco-friend. This review paper gives detail information about adsorbents on both conventional and nanostructured materials, either occur naturally or available commercially. The review also contains properties and parameters which affect the adsorption process with essential clarifications that are given by researchers.
\end{abstract}

Keywords: Water hardness; Absorbents; Industrial effluent; Heavy metals

\section{Introduction}

Water is the most abundant natural resource which is essential to survive, in other words, water is life because it is used for various purposes including drinking, washing, bathing, irrigation, fire-fights, production of industrial materials, and air-conditioning [1]. However, nowadays, due to improper management of industrialization, urbanization, organic and inorganic water pollutants, and agricultural waste on the earth's surface, there is severe water pollution which is resulted in diseases like cholera, Dracunculiasis, Typhoid fever, Diarrhea, Ulcers, Hepatitis, and Arsenicosis are widely spreading across the global [2]. Among the water pollutants, heavy metals are non-biodegradable, which are easily accumulated in living things and highly toxic pollutants so that they are detrimental for human-being as well as aquatic ecosystems [3]. Some of the common heavy metal discharges from industries are $\mathrm{Cd}, \mathrm{Ni}, \mathrm{Cu}, \mathrm{Fe}, \mathrm{Zn}, \mathrm{Ti}, \mathrm{Hg}, \mathrm{Mn}, \mathrm{Cr}, \mathrm{As}$, and $\mathrm{Pb}[4,5]$. When those heavy metals dissolve in water they cause water hardness. Water hardness has less health effect however leads to various disadvantages in both domestic and industrial uses. For example, domestically, water hardness causes wastage of soap during washing and more fuel consumption during cooking as well as industrially, hard water fed to the boiler leads to scale and sludge formation but mainly causes boiler corrosion at the industrial level [6].

There are some methods to eliminate heavy metals such as chemical precipitation [7], ion exchange [8], chemical oxidation [9], reverse osmosis [10], ultrafiltration [11], electrodialysis [12], and adsorption $[13,14]$. From those methods, the adsorption process is the most effective method for removing water hardness due to its low cost, flexibility in design, easy operation mechanism, high efficiency, availability, high-quality treated effluent, and its recyclability. While the other methods have inherent limitations like a large amount of Sludge generation, low efficiency, sensitive operating conditions, and costly disposal $[13,15]$.

\section{Adsorption process}

The term Adsorption was first invented in 1881 by a physicist named Heinrich Kayser. Adsorption is a process in which something takes in another substance which means impurities take by the absorbent material. The molecular species that gets adsorbed on the surface is known as adsorbate while the surface on which adsorption occurs is known as adsorbent. It often goes with desorption which is the inverse process of adsorption. Desorption represents the transfer of adsorbate ions from the adsorbent surface to the solution. Nowadays, adsorption is considered an efficient as well as low-cost technique for removing heavy metal ions from wastewater [16]. This process is flexible in design and operation and allows for producing high-quality treated effluents. Furthermore, since the adsorption is reversible in some cases, adsorbents can be regenerated through desorption [13].

There are two types of adsorption called physical and chemical adsorption. Physical adsorption is in which the increase in the adsorbate concentration at the interface is due to non-specific van der Waals forces and it is weakly specific, reversible and its thermal effect is small while chemical adsorption is caused by chemical reactions between the adsorbate and the adsorbent which create covalent or 
ionic bonds. In addition to these, it is selective, usually irreversible and heat ranges from tens to hundreds of $\mathrm{kJ} / \mathrm{mol}$ [17-20]. The summary of the properties of physical and chemical absorbents are listed in table 1.

Adsorption phenomenon is investigated via experiment as well as theoretical using modeling software such as the modeling of the adsorption equilibrium data, the molecular dynamics study, the density functional theory and the characterization of adsorbent before and after adsorption. Modeling of adsorption data by isotherm is the most appropriate and widely used method. In addition to this, modeling of adsorption data by isotherm can give information of the maximum adsorption capacity, which is important to evaluate the performance of the adsorbents [21].

Modeling of adsorption data by isotherm has been applied in adsorption systems such as the Langmuir model, the Freundlich model, linear model, the Temkin model, the Sips model, and the Brunauer, Emmet, and Teller (BET) model. From these models, the linear, Freundlich, Sips, Temkin, and some other models are empirical models, those lack actual theoretical support [21]. Literally, isotherm means the relationship between the equilibrium adsorbate in the liquid-phase and the equilibrium adsorption amount on the solidphase at a certain temperature [21]

Isotherms can be classified based on their physical meaning and theoretical derivation as empirical models, Polanyis potential theory, chemical adsorption models which describe the monolayer adsorption process; physical adsorption models describes the multilayer adsorption; and ion exchange models, according to their physical meanings [21].

\section{Adsorption empirical isotherms:}

- Linear model (Henry's law):- This model is used to represent a partition of adsorbates between solid and liquid phases. The mechanisms are Van der Waals interactions, the electrostatic interactions and hydrophobic interactions. It has the following form

\section{$\boldsymbol{q}_{e=K C e}$}

Where $\mathrm{q}_{\mathrm{e}}$ is adsorbed amount, $\mathrm{C}_{\mathrm{e}}$ is adsorbate concentrations, and $\mathrm{K}$ is a partition coefficient [21].

- Freundlich isotherm: - This model is one of the most widely used isotherm in adsorption and used to represent nonlinear adsorption phenomenon.

Table 1: The Characteristics of Physical adsorption and Chemical Adsorption $[19,20]$.

\begin{tabular}{|c|c|c|}
\hline $\mathbf{S} / \mathbf{N}$ & $\begin{array}{c}\text { Properties of the physical } \\
\text { adsorption }\end{array}$ & $\begin{array}{c}\text { Properties of the Chemical } \\
\text { Adsorption }\end{array}$ \\
\hline $\mathbf{1}$ & It is a weak process & It is a strong process \\
\hline $\mathbf{2}$ & The activation energy is low & $\begin{array}{c}\text { This type of adsorption is almost } \\
\text { a single-layered phenomenon }\end{array}$ \\
\hline $\mathbf{3}$ & $\begin{array}{c}\text { The force that causes the } \\
\text { adsorption is physical forces }\end{array}$ & $\begin{array}{c}\text { The type of adsorption is caused } \\
\text { by chemical forces }\end{array}$ \\
\hline $\mathbf{4}$ & $\begin{array}{c}\text { The adsorption is not specific } \\
\text { which means it takes place all } \\
\text { over the adsorbent }\end{array}$ & $\begin{array}{c}\text { Chemisorption is highly specific } \\
\text { and takes place at reaction } \\
\text { centers on the adsorbent }\end{array}$ \\
\hline $\mathbf{5}$ & $\begin{array}{c}\text { Surface area, temperature, } \\
\text { pressure, nature of adsorbate } \\
\text { effects the process }\end{array}$ & $\begin{array}{c}\text { Surface area, temperature, } \\
\text { nature of adsorbate effects } \\
\text { chemisorption }\end{array}$ \\
\hline
\end{tabular}

The Freundlich model is given by the following equations:

$q_{e}=K_{F} C e^{1 / n}$

$\log _{e}=\log _{F}+1 / n \log \mathrm{Ce}$

Where $K_{\mathrm{F}}$ and $n$ are constants, the Freundlich model will reduce to the linear model

when $\mathrm{n}=1[21]$.

- Redlich-Peterson (R-P) isotherm:- This model is an empirical hybrid model of the Langmuir and Freundlich model which has been frequently used in the homogeneous or heterogeneous adsorption processes [21].

- Sips isotherm mode:- This model is the most applicable 3-parameter isotherm model for monolayer adsorption. It is the combination of Langmuir and Freundlich [21].

- Temkin isotherm:- Model in which adsorption is presumes as a multi-layer process [21].

Adsorption models based on Polanyi's potential theory: This theory assumes that the adsorption system contains an "adsorption space", where the molecules lose potential energies. The potential energies are independent of temperature, as the potential energy is reached high in the pores or cracks inside the adsorbent. DubininRadushkevich (D-R) model and Dubinin-Astakhov (D-A) model are categorized under Adsorption models based on Polanyis potential theory [21].

a) Chemical adsorption models: These adsorption isotherm models consider the monolayer adsorption process in which the adsorbate molecules are adsorbed in the adsorption sites of the adsorbents. Langmuir and the Volmer isotherm models are the common examples of Chemical adsorption models [21].

b) Physical adsorption models: This adsorption isotherm models simulate the multi-layer adsorption process. The main driving force of the physical adsorption is Van Der Waals force. Brunauer, Emmet, and Teller (BET) and the Jovanovich isotherm models are categorized under the physical absorption model [21].

Above mention theoretical discussion of the adsorption process leads scientific communities to search for material that enables to remove targeted pollutant from the medium. Since our review is target heavy metal removal from wastewater, we are going to discuss the materials have been used adsorbent in the next sections.

\section{Materials Used for Adsorption}

There are various adsorbents which are available either naturally or commercially that are used to remove heavy metals from wastewater [16]. In addition to this, adsorbents are classified as conventional and nanostructured adsorbents based upon their size and efficiency in the removal of impurity from wastewater [22]. In this part of the review, we will see the most frequently used adsorbents which are used to remove heavy metals efficiently.

\section{Conventional absorbents}

Conventional absorbents are the usual types of adsorbents for wastewater treatment [23]. They are inexpensive and available either naturally or easily synthesized from waste materials [23]. Some of the conventional adsorbents are activated carbon, Biomaterial, clay mineral and others will be discussed in the next subtitle.

Activated carbon: Activated carbon is non-graphite, amorphous, microcrystalline, tasteless, and black solid substance which is a form 
of carbon [14]. The porosity that is enclosed by a carbon atom is called activated carbon; the porosity is slit-shaped and has the size of molecules. Activated carbon is made from different materials like coal, coconut shell, hardwood, fruit stones, and synthetic molecular systems [15]. Activated carbon is an excellent adsorbent due to its high specific surface area, porosity, and various oxygen-containing functional groups on the surface [24]. As a result of such novel characteristics, it can attract and retain certain compounds in a preferential way [25]. For example, Activated carbon is used in many industrial applications including separation and purification technologies, catalytic processes, biomedical engineering, and energy storage. This is because of its wide availability, high performance in adsorption processes, surface reactivity, and the versatility to modify its physical and chemical properties for synthesizing adsorbents with very specific characteristics [26].

There are different activation agents which can be classed as physical and chemical activation agents. Some of the physical activations are steam atmosphere, air, $\mathrm{CO}_{2}$, and Chemical activations like $\mathrm{KOH}$, $\mathrm{H}_{3} \mathrm{PO}_{4}$, and $\mathrm{ZnCl}_{2}$. As researches show chemical activation has been proved to be more effective with well-developed porosity than the physical activation method to prepare activated carbon [16].

Activated carbon which is coal-based is expensive so its use has been restricted so further efforts have been taken to convert the agricultural waste into activated carbon because of their availability and inexpensive nature [27-35]. In the last decades, worldwide researchers had proposed several agricultural and industrial wastes as low-cost sources to obtain raw materials for the production of activated carbon. These researchers have in mind not only to lessen its cost of production but also to diminish the environmental impact of agricultural and industrial wastes and to avoid the cost of the associated cost of solid waste handling [25].

Biomaterials: Bio adsorbents are the most advantageous adsorbent for heavy metals due to their high efficiency, availability, and there low cost [36]. Many biological materials have the potential to decrease heavy metals concentration. Some types of bio sorbents are used to remove heavy metals without specific property but others are specific for a certain metal this is the reason why biosorption takes major attention and becomes an active work area [36]. Bio-sorbents obtained from three different sources:

Non-living biomass: Non-living biomass is biomass which shows non-living things which can be obtained from different sources [37]. Non-living biomass has a great advantage over living microorganisms for removal of heavy metals due to their long time usage without any necessity of nutrient supply [37]. Some commonly used non-living biomass will be discussed as well as some of the common non-living biomasses are indicated in Figure 1.

One of the non-living biomass is sugarcane bagasse that is obtained from fibrous material after cane crushing and juice extraction it contains $50 \%$ cellulose, $27 \%$ polyposis, and $23 \%$ lignin. Sugar cane is that captivated mainly in the tropical and subtropic regions. Brazil is the world's most country to produce sugarcane followed by North America and Asia [38].

Sugarcane bagasse can be used in natural and also in modified form. Due to these biological component polymers, sugarcane bagasse is rich in hydroxyl and phenolic groups and these groups can be chemically modified to improve adsorption capacity [39]. Table 2 and 3 lists some researches done on the adsorption capacity of sugarcane bagasse for different types of heavy metals [40-45].
The other non-living biomass is wheat bran. This is a bio sorbent that gains from agricultural waste and it is one of the most economical biodegradable adsorbents which consists of important nutrients like fibers, protein, fatty acid, and minerals. Wheat bran has various organic functional groups with a large internal surface area so it can remove heavy metals from hard water efficiently [46]. The various functional groups like phenolic hydroxyl, methoxy, and carbonyl group give the material a good ability to bind heavy metals [47]. The Table 4 below shows the removal of different types of heavy metals and the adsorption capacity of wheat bran [48-51].

Nowadays many tons of coconuts are produced per year around the world especially in countries like Indonesia, the Philippines, and India. This makes both Coconut coir pith and coconut shells most available and also suitable coconut wastes for the removal of heavy metal [52]. In more than 90 countries coconut palm grown and territories of the world, over 59 million tons were produced in 2016 . The major counties in the world for the production over $72 \%$ of world total coconut are tropical Asia, Indonesia, Philippines, and India [53]. Coconut functional groups like hydroxyl and carboxyl lead to having the material good sorption property [54]. Table 5 shows the adsorption potential of coconut wastes used for the removal of different types of heavy metals. As indicated in this table, Coconut husk, coconut coir pith, coconut shell, and other forms of this biomass have been utilized to remove different types of heavy metals from different sources of industries [55-60].

As we all know chicken eggs are the most worldwide daily food. China is the world's top egg producer and currently, around $45 \%$ of the world's total production of an egg is held by China. The United States and India take second and third place in the production of egg respectively according to data collected in 2012 [61]. Eggshell is also one of the most waste materials across the globe which causes environmental problems as indicated in Figure 2. For example, about 150,000 tons of eggshell is disposed of in the United States every year [62]. But this material has an outstanding mechanical performance, such as high strength, an excellent combination of stiffness, impact resistance, and toughness [63]. Eggshells are used as an adsorbent for heavy metals in modified and also non modified form [64]. Here are some indicative examples of the adsorption capacity of eggshells for heavy metal removal as shown in table 6 [65-69].

The other bio sorbent is Sawdust which is produced in large quantities as solid waste at sawmills. We can obtain sawdust from

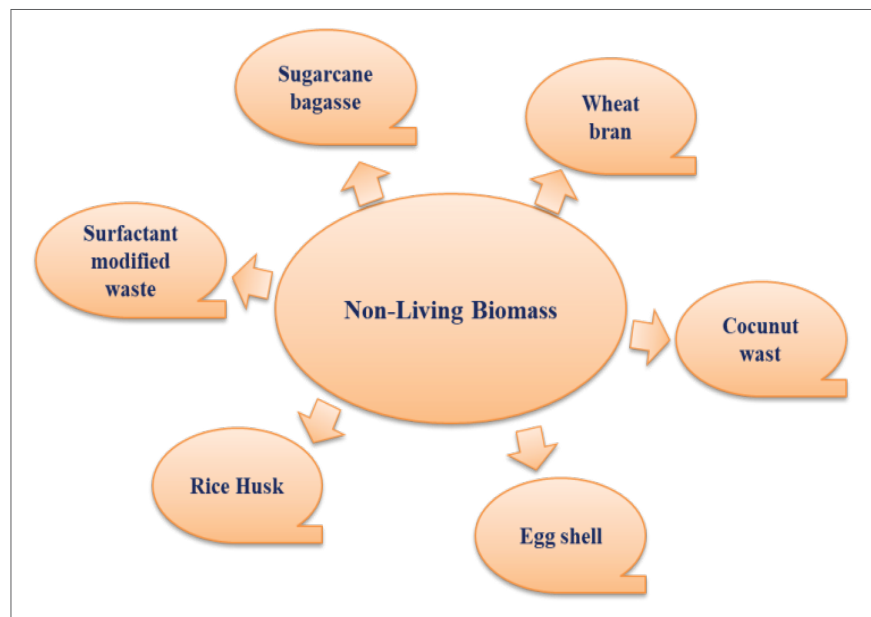

Figure 1: Nonliving biomass. 
wood by cutting, grinding, drilling, or pulverizing [70]. Sawdust contains lignin and cellulose which make it a good adsorbent for heavy metal removal [71]. The adsorption capacity of sawdust for different types of heavy metals is listed in table 7 below [72-77].

Rice husk is an agricultural waste obtained from rice mills as shown in figure 3 contains $32.24 \%$ cellulose, $21.44 \%$ lignin, $21.34 \%$ hemicellulose, and $15.05 \%$ mineral ash [78]. Rice husk is an agricultural waste that can be obtained in many countries that produce rice. Rice husk has a granular structure, chemical stability, good mechanical strength and it is not soluble in water [79]. Silica is derived from rice husk and it results from a good affinity for chromium adsorption while modified silica by iron oxide shows the highest adsorption around $63.69 \mathrm{mg} / \mathrm{g}$ [80]. In addition to this, rice husk is one of the most silica sources we use them as adsorbents for heavy metals and many works

Table 2: Heavy metal removal using activated carbon.

\begin{tabular}{|c|c|c|c|c|c|}
\hline $\mathbf{S} / \mathbf{N}$ & Raw materials & Activation agent & Type of metal removed & $\mathbf{Q}$ (mg/g) & Reference \\
\hline $\mathbf{1}$ & Jatropha wood & & Chromium & 106.4 & {$[28]$} \\
\hline $\mathbf{2}$ & Prawn shell & & Chromium & 100 & {$[29]$} \\
\hline $\mathbf{3}$ & coconut shell & & Cadmium & 93.4 & {$[30]$} \\
\hline $\mathbf{4}$ & Pterocladiacapillacea & & Chromium & 66 & {$[31]$} \\
\hline $\mathbf{5}$ & sugar beet pulp & phosphoric acid & Cadmium & 68.03 & {$[32]$} \\
\hline $\mathbf{6}$ & sugarcane bagasse & Acid modified & Chromium & 15.42 & {$[33]$} \\
\hline $\mathbf{7}$ & olive stones & & Cadmium & 17.665 & {$[34]$} \\
\hline $\mathbf{8}$ & Coconut shell fibers & & Chromium & 12.2 & {$[35]$} \\
\hline
\end{tabular}

Table 3: Heavy metal removal using sugarcane bagasse.

\begin{tabular}{|c|c|c|c|c|c|}
\hline $\mathbf{S} / \mathbf{N}$ & Raw materials & Modified agent & Type of metal removed & $\mathbf{Q}$ (mg/g) & Reference \\
\hline $\mathbf{1}$ & Sugarcane bagasse & & Lead & 47.89 & {$[40]$} \\
\hline $\mathbf{2}$ & Raw sugarcane bagasse & & Mercury & 35.71 & {$[41]$} \\
\hline $\mathbf{3}$ & Sugarcane bagasse & acrylonitrile and hydroxylamine & Cooper & 101.01 & {$[42]$} \\
\hline $\mathbf{4}$ & Sugarcane bagasse & & Cadmium & 6.79 & {$[43]$} \\
\hline $\mathbf{5}$ & Sugarcane bagasse & colonized by Pleurotusostreatus & Lead & 47.89 & {$[40]$} \\
\hline $\mathbf{6}$ & sugarcane bagasse & Acrylic-modified & Cooper & 265.252 & {$[44]$} \\
\hline $\mathbf{7}$ & sugarcane bagasse & Sodium bicarbonate & Cooper & 114 & {$[45]$} \\
\hline
\end{tabular}

Table 4: Heavy metal removal using modified wheat bran.

\begin{tabular}{|c|c|c|c|c|c|}
\hline $\mathbf{S} / \mathbf{N}$ & Raw materials & Modified agent & Type of metal removed & Q (mg/g) & Reference \\
\hline $\mathbf{1}$ & Wheat bran & & Chromium & 93 & {$[48]$} \\
\hline $\mathbf{2}$ & Wheat bran & & Lead & 62 & {$[48]$} \\
\hline $\mathbf{3}$ & Wheat bran & & Mercury & 70 & {$[48]$} \\
\hline $\mathbf{4}$ & Wheat bran & sulphuric acid & Chromium & 133 & {$[49]$} \\
\hline $\mathbf{5}$ & Wheat bran & tartaric acid & Chromium & 5.28 & {$[50]$} \\
\hline $\mathbf{6}$ & Wheat bran & Sulfuric acid & Copper & 51.5 & {$[49]$} \\
\hline $\mathbf{7}$ & Wheat bran & Sulfuric acid & Cadmium & 101 & {$[50]$} \\
\hline
\end{tabular}

Table 5: Heavy metal removal using coconut waste.

\begin{tabular}{|c|c|c|c|c|c|}
\hline $\mathbf{S} / \mathbf{N}$ & Raw materials & Modified agent & Type of metal removed & $\mathbf{Q}$ (mg/g) & Reference \\
\hline $\mathbf{1}$ & Coconut husk & & Chromium & 18.25 & {$[55]$} \\
\hline $\mathbf{2}$ & coconut coir pith & Amine-modified & Chromium & 12.43 & {$[56]$} \\
\hline $\mathbf{3}$ & Coconut shell charcoal & oxidized with nitric acid & Chromium & 10.88 & {$[57]$} \\
\hline $\mathbf{4}$ & Coir pith & Cadmium & 93.4 & {$[58]$} \\
\hline $\mathbf{5}$ & Coir pith & $\begin{array}{c}\text { Hexadecyl trimethyl ammonium } \\
\text { bromide }\end{array}$ & Chromium & $76.3,1.24$ & {$[52]$} \\
\hline $\mathbf{6}$ & Coconut shell carbon & & Lead & 26.5 & {$[59]$} \\
\hline $\mathbf{7}$ & Coir pith & Cobalt & 12.82 & 11.56 & 15.95 \\
\end{tabular}

Citation: Tamiru M, Bekele G (2020) Various Absorbents and Parameters Affecting Removal of Water Hardness from Wastewater: Review. Int J Water Wastewater Treat 6(3): dx.doi.org/10.16966/2381-5299.173 


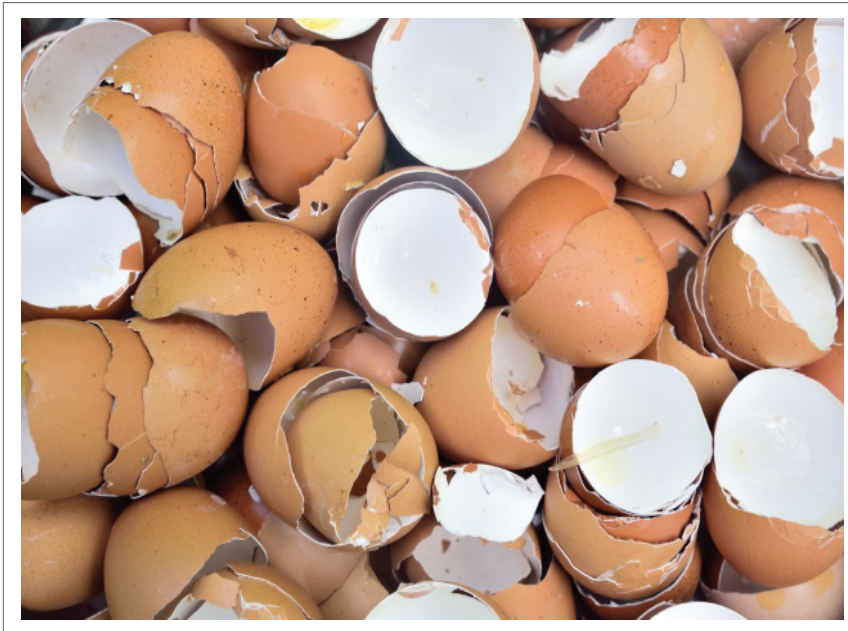

Figure 2: Deposit of Egg shells.

Table 6: Heavy metal removal using Eggshell.

\begin{tabular}{|c|c|c|c|c|c|}
\hline $\mathbf{S} / \mathbf{N}$ & $\begin{array}{c}\text { Raw } \\
\text { materials }\end{array}$ & $\begin{array}{c}\text { Modified } \\
\text { agent }\end{array}$ & $\begin{array}{c}\text { Type of metal } \\
\text { removed }\end{array}$ & $\mathbf{Q ~ ( m g / g ) ~}$ & Reference \\
\hline $\mathbf{1}$ & Eggshell & & Chromium & 1.45 & {$[65]$} \\
\hline $\mathbf{2}$ & Eggshell & & Chromium & 160 & {$[66]$} \\
\hline $\mathbf{3}$ & Eggshell & & Copper & 44.843 & {$[67]$} \\
\hline $\mathbf{4}$ & Eggshell & $\begin{array}{c}\alpha-\mathrm{FeOOH} \\
\text { (F-ES) }\end{array}$ & Chromium & 41.57 & {$[68]$} \\
\hline $\mathbf{5}$ & Eggshell & PEI & Chromium & 160 & {$[69]$} \\
\hline
\end{tabular}

Table 7: Heavy metal removal using sawdust.

\begin{tabular}{|c|c|c|c|c|c|}
\hline $\mathbf{S} / \mathbf{N}$ & $\begin{array}{c}\text { Raw } \\
\text { materials }\end{array}$ & $\begin{array}{c}\text { Modified } \\
\text { agent }\end{array}$ & $\begin{array}{c}\text { Type of } \\
\text { metal } \\
\text { removed }\end{array}$ & $\mathbf{Q ~ ( m g / g ) ~}$ & Reference \\
\hline $\mathbf{1}$ & Sawdust & $\begin{array}{c}\text { Sodium } \\
\text { hydroxide }\end{array}$ & Cadmium & 73.62 & {$[72]$} \\
\hline $\mathbf{2}$ & Sawdust & $\begin{array}{c}\text { Sodium } \\
\text { hydroxide }\end{array}$ & Nickel & 10.47 & {$[73]$} \\
\hline $\mathbf{3}$ & Sawdust & Formaldehyde & Chromium & 3.6 & {$[74]$} \\
\hline $\mathbf{4}$ & Sawdust & Sulfuric acid & Copper & 13.95 & {$[75]$} \\
\hline $\mathbf{5}$ & Sawdust & $\begin{array}{c}\text { Hydrochloric } \\
\text { acid }\end{array}$ & Chromium & 1.74 & {$[70]$} \\
\hline $\mathbf{6}$ & Sawdust & $\begin{array}{c}\text { Formaldehyde } \\
\text { in Sulfuric acid }\end{array}$ & Lead & 9.78 & {$[76]$} \\
\hline $\mathbf{7}$ & Sawdust & $\begin{array}{c}\text { Reactive } \\
\text { Orange 13 }\end{array}$ & Zinc & 17.09 & {$[77]$} \\
\hline
\end{tabular}

have been conducted and some of them are listed in the table 8 [81-83].

Lastly, surfactants also considered as non-living biomass are compounds that decrease the surface and interfacial tension and stabilize the interface [84]. The nature of their hydrophilic group leads them to be cationic, anionic, non-ionic, and zwitterion. This behavior of Surfactant modified adsorbents leads to superior removal efficiency and promote selective adsorption [84]. Agricultural wastes have been

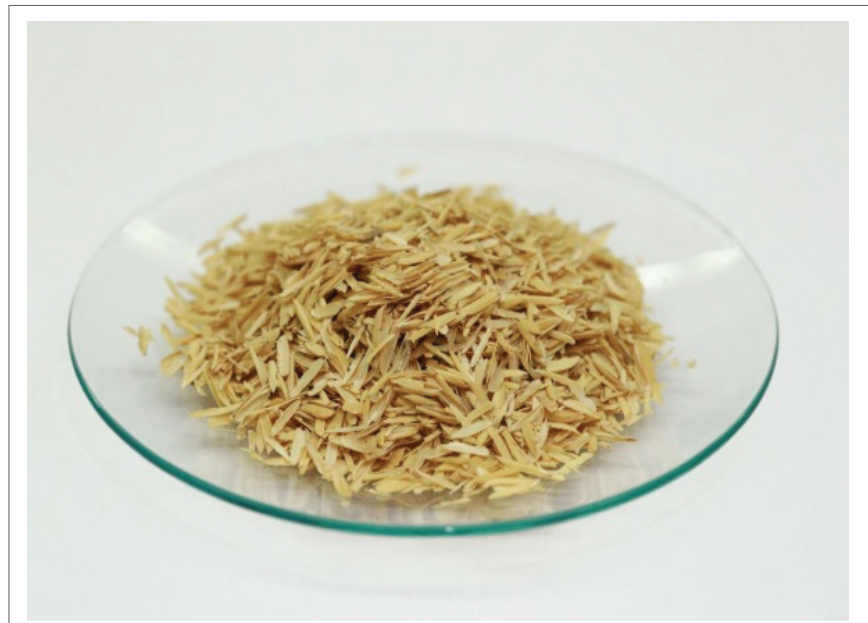

Figure 3: Rice husk for removal of heavy metal.

modified using various surfactants $[85,86]$. We can see surfactants and their effects on the removal of heavy metals on the above tables which are constructed for different kinds of non-living biomass.

Algal biomass: Alga is a photosynthetic eukaryotic large and diverse group of an organism and their biomass is used for a wide variety of applications [87]. Alga stands for singular noun and requires a singular verb while algae are for plural noun uses a plural verb. Algae have been used as fertilizer, food, and feed for centuries however currently they are used in so many applications like biomaterials, nutraceuticals, biofuels, pharmaceuticals, and bioremediation [88]. Algae used as a new adsorbent for heavy metal ion due to its availability, low cost, regular quality, and high adsorption capacity [89]. Algae are renewable natural biomass proliferating the ability to be everywhere and abundantly in the Mediterranean zones of the world. They take the attention of many researchers as organisms to be used as new adsorbents to remove heavy metals [16,89].

There are different kinds of marine algae called red algae, green algae, and brown algae the main difference between those algae is their cell walls where biosorption occurs [90]. Red algae consist of cellulose in the cell wall however the capacity of biosorption is mainly dependent on the presence of sulfated polysaccharides. Green algae also have cellulose in the cell wall but with a high content of bonded proteins. brown algae cell walls contain cellulose, alginic acid, and polymers of mannuronic and guluronic acids complexed with metals and other polysaccharides [90] (Figure 4).

Algae are also classified by size as macroalgae or microalgae [91,92].

Macroalgae: - Are multicellular, large size seaweed, and visible with the naked eye without the aid of a microscope [92]. Microalgae is a term used for seaweeds and other benthic (attached to the bottom) marine algae collectively that are visible to the naked eye. The Larger macroalgae are also referred to as seaweeds which are not really "weeds" [91]. Macroalgae have different forms, they include the simplest form with simple branching structures like simple crusts, foliose (leafy), and filamentous (threadlike), and also more complex forms include which have highly specialized structures [91]. The size of coral reef macro algae could be in the range between few millimeters to plants up to 3-4 m high [91].

Macroalgae can be classified into different "functional form" groups, based on ecological characteristics and growth form 

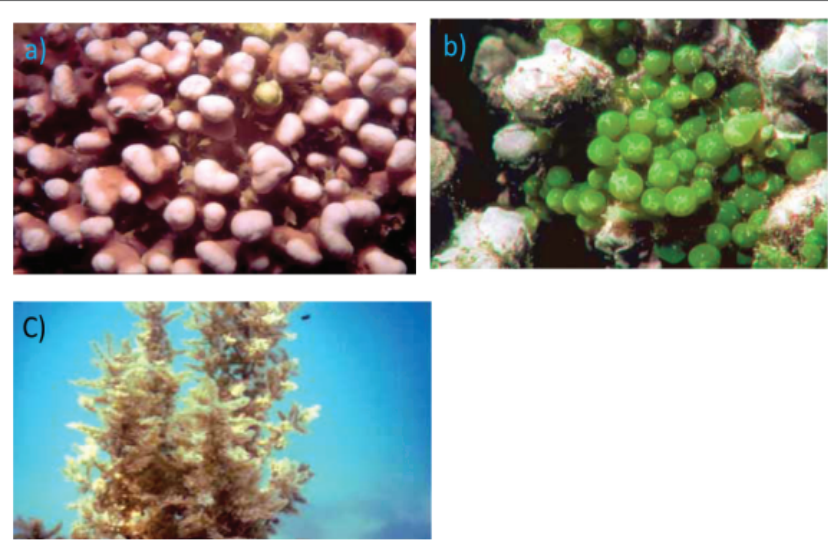

Figure 4: a) Red algae, b) The green macroalga, and c) Brown macroalgae [91]

Table 8: Heavy metal removal using rice husk.

\begin{tabular}{|c|c|c|c|c|c|}
\hline $\mathbf{S / N}$ & $\begin{array}{c}\text { Raw } \\
\text { materials }\end{array}$ & Modified agent & $\begin{array}{c}\text { Type of } \\
\text { metal } \\
\text { removed }\end{array}$ & $\mathbf{Q}$ (mg/g) & Reference \\
\hline $\mathbf{1}$ & Rice husk & Water washed & Cadmium & 8.58 & {$[81]$} \\
\hline $\mathbf{2}$ & Rice husk & $\begin{array}{c}\text { Sodium } \\
\text { hydroxide }\end{array}$ & Cadmium & 20.24 & {$[81]$} \\
\hline $\mathbf{3}$ & Rice husk & $\begin{array}{c}\text { Sodium } \\
\text { bicarbonate }\end{array}$ & Cadmium & 16.18 & {$[81]$} \\
\hline $\mathbf{4}$ & Rice husk & Epichlorohydrin & Cadmium & 11.12 & {$[81]$} \\
\hline $\mathbf{5}$ & Rice husk & Ozone-treated & Chromium & 13.1 & {$[82]$} \\
\hline $\mathbf{6}$ & Rice husk & Iron oxide & Chromium & 63.69 & {$[80]$} \\
\hline $\mathbf{7}$ & Rice husk & Tartaric acid & $\begin{array}{c}\text { Copper } \\
\text { Lead }\end{array}$ & $\begin{array}{c}31.85 \\
120.48\end{array}$ & {$[83]$} \\
\hline
\end{tabular}

instead of systematic and taxonomic classification. The Functional groups help us to understand the distribution of algal communities and their responses to environmental factors can be understood from their functional group. Algaes that have the same ecological characteristics have similar responses to environmental pressures, however taxonomically related algae mostly have different ecological properties and responses. In addition to this classification of algae in the functional approach is useful due to algae are very difficult to identify to species level, and it helps to characterize algal communities in ecological studies on coral reefs [91].

Algal turfs: Includes many species of minute algae, the major is filamentous. They have fast growth, high productivity, and high colonization rates [91].

Fleshy macroalgae: Are forms of large algal that are, more rigid and anatomically more complex than algal turfs. They are abundant in low herbivory zones [91].

Crustose algae: Are hard plants which generally have slow growth rate and they grow as crusts, adhering closely to the substrate with a painted like layer than the atypical plant [91].

Macroalgae play several roles in different area including major contributions to primary production (the basis of food-webs forms and the overall amount of this organic matter produced in the ecosystem), bioerosion, construction and cementation of reef framework, facilitation of coral settlement, and creation of habitats for other reef species [91].

Microalgae: are single cellular, small size microscopic organisms they found in all the aquatic systems like freshwater, seawater, hypersaline lakes, and also in desserts, and arctic ecosystems [92]. Microalgae's are Subdivided into eukaryotic and prokaryotic algae, eukaryotic possessing. Outlined cell organelles such as nuclei, mitochondria, chloroplasts, and prokaryotes are primitive, possessing the simpler cellular structure of bacteria. They convert light energy and carbon dioxide $\left(\mathrm{CO}_{2}\right)$ into biomass and their mechanism in the process of photosynthesis is similar to land-based plants, however, a simple cellular structure has efficient to access water, $\mathrm{CO}_{2}$, and other nutrients, so they are more efficient in converting solar energy into biomass [93]. The three classes of microalgae-based on abundance are diatoms (Bacillariophyceae) green microalgae (Chlorophyceae) and the golden algae (Chrysophyceae) [94].

Microalgae are energy-rich feed stocks and received so much attention due to high yields and multiple applications and also their facile adaptability to grow in the photo bioreactors or open ponds. Microalgae have many advantages such as higher productivity in a few days, they easily adapt to a new environment, and high-lipid content [93]. Microalgae can be used for several applications such as biofuels, pharmaceuticals, health supplements, and cosmetics. They are also used in wastewater treatment and atmospheric $\mathrm{CO}_{2}$ mitigation. In addition to this microalgae are used to produce several bioproducts, like proteins, polysaccharides, pigments, lipids, vitamins, antioxidants, and bioactive compounds [92]. Microalgae are used to accumulate heavy metals from wastewater and some can degrade polyaromatic hydrocarbons and other organics. Microalgae have a very important role in wastewater treatment; they have used to the removal of heavy metals, nutrients, organic contaminants, and pathogens from waste water [94-100] (Table 9).

There are some works listed in the next table to show the adsorption capacity of algae on heavy metal removal.

Microbial biomass (bacteria, fungi, and yeast): Fungi biomass produces a high yield, is easy to grow, and also can be manipulated genetically and morphologically. Fungi bio sorbents include Rhizopus arrhizus [101], Aspergillus niger [102], Lentinus edodes [103], Saccharomyces cerevisiae etc. Despite the characteristic of broad sources, low-cost and rapid adsorption the separation of bio sorbents is difficult after the adsorption process [104].

Bacteria are the most abundant microorganisms and bacterial removal of metal ions from wastewater has been considered as being highly efficient [105]. Bacteria and cyanobacteria cell wall has the potential to capture heavy metals due to the fabric which is negatively charged group [106]. There are several processes to remove heavy metals like precipitation, biosorption to cell walls, transport across the cell membrane, entrapment in extracellular capsules, oxidation/ reduction, and complexation [107]. Bacteria species such as Bacillus sp, Micrococcus luteus, Pseudomonas cepacia, Bacillus subtilis, and Streptomyces coelicolor have been used by researchers for copper removal from wastewater $[108,109]$.

Yeast is a fungus that has a larger size than bacteria and it has a nucleus and associated cytoplasmic organelles like other eukaryotic organisms. The cytoplasm present in the living cells is important to interact with metal ions and after entering into the cells, the heavy 
Table 9: Heavy metal removal using Algae.

\begin{tabular}{|c|c|c|c|c|}
\hline \multirow{4}{*}{ Algal } & Biomass & $\begin{array}{c}\text { Type of metal } \\
\text { removed }\end{array}$ & $\mathbf{Q ~ ( m g / g ) ~}$ & Reference \\
\cline { 2 - 5 } & Sargassum sp. & Zinc & 118 & {$[95]$} \\
\cline { 2 - 5 } & Apanothece halophytic & Zinc & 133 & {$[96]$} \\
\cline { 2 - 5 } & Fucusvesiculosus & Lead & 270 & {$[97]$} \\
\cline { 2 - 5 } & \begin{tabular}{c} 
Ascophyllumnodosum \\
\cline { 2 - 5 }
\end{tabular} & Cadmium & 215 & {$[98]$} \\
\hline & $\begin{array}{c}\text { Sargassum } \\
\text { Muticum }\end{array}$ & Copper & 71 & {$[99]$} \\
\hline & $\begin{array}{c}\text { Cystoseira } \\
\text { Crinitophylla }\end{array}$ & Copper & 160 & {$[100]$} \\
\hline
\end{tabular}

metal ions are separated into compartments for removal [110]. Researcher shows that the brewing industry by-product waste beer yeast is a cheap and promising adsorbent for copper removal from wastewater [111]. The following table show adsorption capacities of Microbial biomass (bacteria, fungi, and yeast) on different types of heavy metals [112-120] (Table 10).

Membrane Bioreactor (MBR) is an optional way to apply water reuse applications in wastewater treatment Because of its quality, compact size, removal efficiency, and the least amount of daily waste activated sludge. Fouling in the membrane is a major difficulty that significantly increases the maintenance and operation costs and also, deposition of the cell on the membrane, exertion of Extracellular Polymeric Substance (EPS), and Soluble Microbial Products (SMP) cause severe biofouling [121].

Nitrification is an aerobic process that is performed by nitrifying bacteria by comparing with heterotrophs released different metabolites in the activated sludge. During Aerobic heterotrophic metabolism, large amount of waste activated sludge are produced and the activity of Nitrosomonas and Nitrobacteria are prevented by accumulation of heterotrophic bacteria and their waste. Heterotrophs assimilate ammonia and consume oxygen before reaching nitrifies. Nitrifies outcompeted by heterotrophic bacteria because of the presence of high amount of organic loading rates [121].

Nitrification is the most known reaction of Alkanity consumption and also in fact that for nitrify growth and activity. Alkality is used to supply the appropriate abiotic factors. The shortage of foulding and alkalinity are two different problems that lately make microorganism de activated. So, the removal of foulding is much harder and time consuming than alkanity supply for the microorganism. waste water containing low $\mathrm{C} / \mathrm{N}$ ratio the A Nitrifying-Enriched Activated Sludge (NAS) approach low foulding and increasing the preparation in 2.5 times higher than Conventional Activated Sludge (CAS) and reducing in microbial product in NAS had different fulfill the result [121].

A unique strategy for nutrient recycling manifested by the symbiotic algae bacteria and also the removal of contaminant in municipal and industrial water treatment. Algae produce oxygen which used as election accepted by aerobic bacteria, this stimulating the biodegradation of the substrate through by oxygenic photosynthesis. Algae have a networking potential for competing microbial species such as pathogens, and also the improvement of the dissolved oxygen concentration, $\mathrm{PH}$, and temperature. Different
Table 10: Heavy metal removal using Microbial biomass.

\begin{tabular}{|c|c|c|c|c|}
\hline \multirow{5}{*}{ Bacterial } & Biomass & $\begin{array}{l}\text { Type of } \\
\text { metal } \\
\text { removed }\end{array}$ & $\begin{array}{c}\mathrm{Q} \\
(\mathrm{mg} / \mathrm{g})\end{array}$ & Reference \\
\hline & Thiobacillusferroxidase & Chromium & 82 & [112] \\
\hline & Bacillus firmus & Copper & 381 & [113] \\
\hline & Streptomyces rimosus & Lead & 135 & [114] \\
\hline & Pleurotussapidus & Lead & 69.77 & [115] \\
\hline \multirow[t]{2}{*}{ Fungal } & Phanerochaetechrysosporium & Cadmium & 127 & [116] \\
\hline & Penicilliumchrysogenum & Lead & 116 & [117] \\
\hline \multirow{3}{*}{ Yeast } & Baker's yeast & Copper & 65 & [118] \\
\hline & $\begin{array}{l}\text { Saccharomyces } \\
\text { cerevisiae yeast }\end{array}$ & Copper & 9.01 & [119] \\
\hline & $\begin{array}{c}\text { Saccharomyces } \\
\text { cerevisiae biomass }\end{array}$ & Copper & 2.59 & [120] \\
\hline
\end{tabular}

unicellular micro algae including chlamydonas, chlorella, vulgaris and phormidium have been used for algae bacteria culture. Algae is used for govern the consumption of $\mathrm{CO}_{2}$ and also to provide safe and cost effective alternative to mechanical aeration. Removal of nitrogen and phosphorous need using more than $90 \%$ of could achieve 5:1 (algae/ sludge, w/w) culture and also in the conventional activated sludge process a high organic loading rate cause higher amount of sludge production [122].

The result of ammonium removal is scarcely distinguishable from those who investigated inoculation ratios. The concentration of nitrite in nitrite community follows a boom and bust test and famine) cycle. When C.vulgaris proposition increase the nitrify actively was decrease because of it is lower weight percentage increase the assimilation and carbon capture activity of C.vulgaris. Phosphate is used for the sustainable growth of C.vulgaris and luck of phosphate compounds in media leads to the suppression of photo synthesis. Conversion of $\mathrm{CO}_{2}$ in to other soluble carbon is one of main part of carbon cycle and also carbon dioxide [122].

Sequestration is the chemistry of $\mathrm{CO}_{2}$ after being dissolved in water is completely dependent on $\mathrm{PH}$ via the equilibrium reaction. The inorganic carbon demand increased from B 10 to B 90 through the nitrification activity of nitrifiers and the higher assimilation. In this study Chlorella vulgaris and NAS by conduct to examine the removal of generation and also to the removal of ammonia. B 10 requiring 7 days as the other composition greater than 14 days the maximum $\mathrm{p}$ removal achieve B100 [122].

In the culture and organic metabolite generation, the analysis of EPS and SMP demonstrated a positive relation between the proportion of C.vulgaris and also membrane bio reaction can remove nutrients more efficiently and it could influence the interaction the C.vulgaris - NAS culture. Various carcinogenic or genotoxic by product such as trihalomethane is formed when chlorine reacts with EPS and SMP in effluents [122].

Clay minerals: Clay is a type of small particle found naturally on or near some planetary surfaces. water, alumina, silica, and weathered rocks are the main components of clay [123]. The basic structure of clay minerals consist of repeating units of Si-O tetrahedral $(\mathrm{T})$ and $\mathrm{Al}-\mathrm{O}$ octahedral $(\mathrm{O})$ that form layers or sheets that bind together by sharing oxygens as shown in figure $2[124,125]$. Clay minerals characterized 
by layered structural units made up of one or two tetrahedral silica sheets around an octahedral arrangement consist of $\mathrm{Fe}, \mathrm{Mg}$, or $\mathrm{Al}$ atoms surrounded by six hydroxyl or oxygen atoms aluminum sheet [126]. Clays have different physical properties like hardness, fineness of particles, good plasticity, appropriate shrinkage, associativity high refractoriness, and surface decoration [127]. Clays have a complex porous structure such as small particle sizes and high specific surface area and this leads to facilitate physical and chemical interactions with dissolved material. Crystallinity, electrostatic repulsion, adsorption, and some cation exchange reactions are causes for the interaction [127] (Figure 5).

There are three main groups of clays called kaolinite, bentonites, and mica [18].

Kaolin group: Minerals are one of the most common clay forms in warm and humid climate [128]. It has a 1:1 layered structure which comprised a tetrahedral $\mathrm{SiO}_{4}$ sheet and an octahedral sheet. Kaolinite application in water purification is growing rapidly with the conjunction of other clay minerals and $\mathrm{H}^{+}$ion promotes the adsorption of heavy metal ions which is released from the edge of the layer structure in acidic environments, like lead, copper, mercury, and cadmium from aqueous solution [129].

Bentonite: Is a kind of sedimentary rock comprised largely from clays that have a typical 2:1 layer structure and of $\mathrm{Na}^{+}, \mathrm{Ca}_{2}{ }^{+}$, and $\mathrm{Li}$-ions located between the layers in high concentrations. The octahedral and tetrahedral sheets are in such a pattern that the tips of the tetrahedral in each silica sheet and one of the hydroxyl layers in the octahedral sheet constitute a single layer. Due to the constant expansion of the layers, the distance between the 2:1 layers is not determined. Among other types of clay minerals bentonites mainly montmorillonite possess the greatest cation exchange capacity. It takes much attention due to its highly selective and regenerable and found to be cheaper as compared to Activated Carbons [130].

Mica group: Have also 2:1 layer however the isomorphic substitution occurs in the tetrahedral layer by mica group clay minerals where $\mathrm{Si}^{4+}$ is replaced by $\mathrm{Al}^{3+}$. Common mica group minerals consist of phlogopite, muscovite, and biotite. Most natural illites are mixed layers of muscovite-like minerals and smectite-like minerals also mica groups are commonly known as illite [131]. Illites make up the bulk of ancient shales, and illitization reactions are common during late diagenesis of siliciclastic materials [132-145] (Table 11).

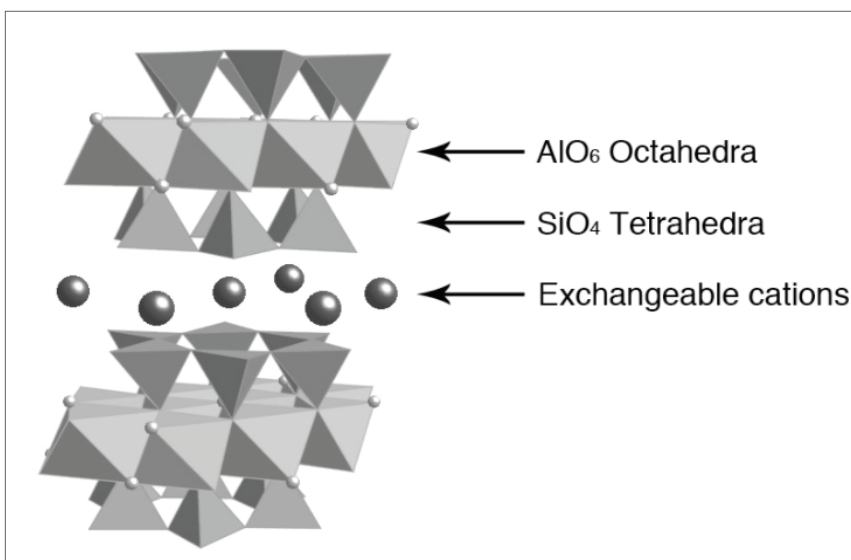

Figure 5: Crystal structure of clay [125].
Zeolite: Zeolites are among the best adsorbents because they are composed of three-dimensional crystalline, hydrated aluminosilicates made from the interlinked tetrahedra of silica $\left[\mathrm{SiO}_{4}\right]^{4-}$ and alumina $\left[\mathrm{AlO}_{4}\right]^{5}$. The two major characteristics of the open tetrahedral framework of zeolites are Ion exchange and reversible dehydration [146]. Zeolites have much scientific and industrial significance because of their good ion exchange properties, high surface area, nontoxicity, low cost, abundance, and hydrophilic characteristics. Due to those characteristic zeolites are applicable in many areas like drying, purification, water softening, environmental treatment, radioactive waste storage, catalytic activities, and so on. Zeolites are mostly applicable in the cause of water treatment due to their satisfactory potential for removal of metal ions from solution [6,147] (Figure 6).

Based on their pore size Porous materials are classified into microporous and mesoporous materials. Materials with pore diameter from 20 to $500 \AA$ are known as Mesoporous materials. They have large surface areas and provide many numbers of sites where sorption processes can occur. So those materials have certain applications in catalysis, separation, and many other fields. From reported materials, some kinds of silica and alumina, mesoporous oxides of cerium, niobium, tantalum, titanium, tin, and zirconium are the most known mesoporous materials. Materials with pore diameters of less than $2 \mathrm{~nm}$ called Microporous. These materials are mainly used in the laboratory to facilitate the contaminant-free exchange of gases, bacteria, and other contaminants so they allow the sterile environment in the contained area. Zeolites are also known members of this family [148-150].

Zeolite occurs naturally [151] but is also can be synthesized [152]. Zeolite can be classified as natural zeolite and synthetic zeolite based on the source in which they occur. Both natural and synthetic forms of zeolite is available in commercial quantity. The variable phase purity of the natural zeolite and the chemical impurities make a difference between the natural and the synthetic zeolite. Both natural and synthetic zeolites are used for different applications [152].

Natural Zeolite: Natural zeolite is a naturally occurring zeolite that was first discovered by a Swedish mineralogist Freiherr Axel

Table 11: Heavy metal removal using clay mineral.

\begin{tabular}{||c|c|c|c|}
\hline \multirow{4}{*}{} & $\begin{array}{c}\text { Type of metal } \\
\text { removed }\end{array}$ & $\mathbf{Q}$ (mg/g) & Reference \\
\cline { 2 - 4 } & Cadmium & 41.84 & {$[133]$} \\
\cline { 2 - 4 } & Copper & 10.78 & {$[134]$} \\
\cline { 2 - 4 } & Cobalt & 11 & {$[135]$} \\
\cline { 2 - 4 } & Nickel & 140.84 & {$[136]$} \\
\cline { 2 - 4 } & Zinc & 4.95 & {$[137]$} \\
\cline { 2 - 4 } & Cadmium & 11.2 & {$[138]$} \\
\cline { 2 - 4 } & Copper & 17.87 & {$[139]$} \\
\cline { 2 - 4 } & Cobalt & 0.91 & {$[140]$} \\
\cline { 2 - 4 } & Nickel & 92.59 & {$[141]$} \\
\cline { 2 - 4 } & Zinc & 8.21 & {$[142]$} \\
\cline { 2 - 4 } Mica & Cadmium & 22.17 & {$[143]$} \\
\cline { 2 - 4 } & Copper & 42.43 & {$[143]$} \\
\cline { 2 - 4 } & Nickel & 6.68 & {$[144]$} \\
\cline { 2 - 4 } & Zinc & 98.04 & {$[145]$} \\
\hline
\end{tabular}




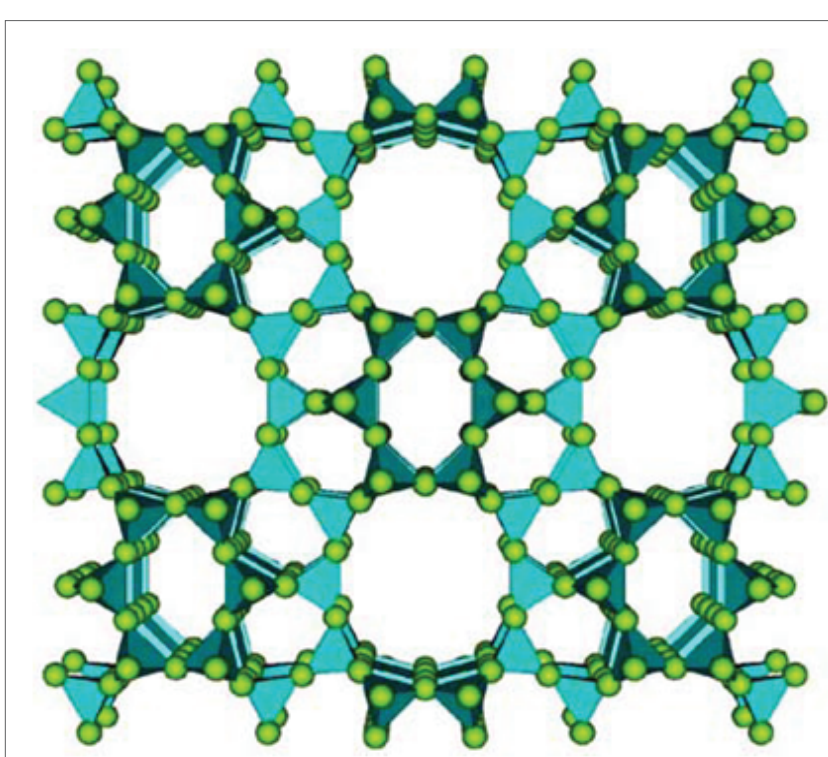

Figure 6: Crystal structure of zeolite [148].

Fredrick Cronsted, during the collection of minerals in a copper mine. The new mineral called zeolite because of its characteristic observed by crested during blowpipe tests on the new crystals he invents. Zeolite is derived from two Greek words "zeo" to boil and "lithos" a stone. Since the first zeolite discovered by crusted approximately 50 natural zeolites have been detected. These minerals were known before constant recognition of it as a distinct mineralogical species. The minerals were used as dimension stones in the construction of pyramids and also as temples in Mexico, in Cappadoccia used they built houses and churches Romans also used it for the production of pozzolanic cement. Hunters and geologists realized crystals of different zeolites in the cavities of basaltic and volcanic rocks.

However major geological discoveries have revealed the widespread occurrence of natural zeolites after 1950. Since the beginning of the last century Natural zeolites whose origin is sedimentary were used for different applications in different areas of environmental protection. These applications are due to important properties exhibited in these materials, such as cation exchange, alkali metals reactivity, physical adsorption and expansion tendency, thermal insulation, compressive strength, and durability [153-155].

Some Countries have resources of these minerals and production potentials such as Cuba, the USA, Russia, Japan, Italy, South Africa, Hungary, Bulgaria, and Turkey have substantial zeolite resources. there are no certain figures determined in the world amount of zeolites but it is well known that even the mineral contents and kind vary they are available on all the continents [156].

Natural zeolites subdivide into several subgroups based on their structures some of them are:- Natrolite which is a fundamental chainlike unit, Harm tome the chains are linked laterally and contain four and eightfold rings, Chabazite the structure exist single or double six-fold rings of tetrahedral, Faujasi tetetrahedra form pseudocubic symmetry form due to joined Cubo octahedral cage-like units. Modernite containing five-fold rings of Tetrahedral which can be linked in various ways and Heulandite [157-160] (Table 12).
Surface activity exists in this material take a great appreciation because the material shows superficial interacting with large organic molecules, charge exchange capacity, and polar adsorption [155]. Nowadays the application of natural zeolites is limited due to more interesting properties of synthetic zeolite such as greater thermal stability as well as good properties as specific catalysts. Synthetic zeolite gets more interest than natural zeolites due to the coast purification method as variable phases and chemical impurities. Contrarily at a time where uniformity and purity are not useful natural zeolite may get favor due to its cheapness [152].

Synthetic Zeolite : The idea of Zeolite synthesis was originated by Richard Barrer and Robert Milton in the 1940s. during 1940-1950 synthesis of zeolite A, X and Y open a way to introduce the idea of industrial adsorbents class in 1954, and after discovering the final structures of zeolite-A and zeolite-X in 1959 they come by the name hydrocarbon conversion catalysts [161]

Synthetic zeolites are also called molecular sieves which are crystalline aluminosilicates manufactured by heat. Zeolites identify as minerals of natural origin however recently more than one hundred different types of zeolite are synthesis [162]. Zeolite was formed when a reaction occurs between volcanic ash and water of basic lakes by taking several thousands of years. However, in laboratory conditions, it takes a short parried of time and can be made by hydrothermal processes from natural raw materials or synthetic silicates [162].

Zeolites where generally, the non-framework cations are replaceable and the molecules of waters are also removable and they could found several elements in the pores of synthesized zeolites; metal-silicates and microporous alumina phosphate was included in classes of molecular sieves [161]. While the aperture extent or the planar range within a crystal is smaller than $20 \AA$ it is determined as microporous and shows porosity or compactness.

Several types of zeolite by using $\mathrm{SiO}_{2}$ either lower or higher than the natural zeolite in the same framework type. Stronger-acid catalytic activity, hydrothermal stability, and high hydrophobicity are the characteristics of adsorbent with high $\mathrm{SiO}_{2}$. Opposing this lower $\mathrm{SiO}_{2}$ leads to greater cation exchange capability with higher absorbance for polar molecules. Sometimes elements like $\mathrm{Ga}^{3+}$ or $\mathrm{Ge} 4+$ have been substituting $\mathrm{Al}^{3+}$ and $\mathrm{Si}^{4+}$ partially or wholly in some cases, this strong element replacement gives more definite substitutional disorders on the information. Many sources such as coal ash, SCBA, and rice husk ash were used to prepare synthesized zeolites [163-166]. There are two groups to synthesize crystalline materials which are solidstate reaction and liquid phase reaction. In the cause of solid-state reaction the temperature used is above $300^{\circ} \mathrm{C}$ to overcome difficulties

Table 12: Heavy metal removal using natural zeolite.

\begin{tabular}{|c|c|c|c|c|}
\hline $\mathbf{S} / \mathbf{N}$ & Raw materials & $\begin{array}{c}\text { Type of metal } \\
\text { removed }\end{array}$ & $\mathbf{Q}$ (mg/g) & Reference \\
\hline $\mathbf{1}$ & Natural mordenite & Chromium & 3.5 & {$[158]$} \\
\hline $\mathbf{2}$ & Natural scolecite & Chromium & 14.5 & {$[158]$} \\
\hline $\mathbf{3}$ & Clinoptilolite & Chromium & 4.1 & {$[159]$} \\
\hline $\mathbf{4}$ & Clinoptilolite & Lead & 78.7 & {$[159]$} \\
\hline $\mathbf{5}$ & Bentonite & Cadmium & 9.44 & {$[160]$} \\
\hline $\mathbf{6}$ & Na-clinoptilolite & Copper & 4.8 & {$[160]$} \\
\hline $\mathbf{7}$ & Na-clinoptilolite & Lead & 91.2 & {$[160]$} \\
\hline
\end{tabular}


in the transportation of molecules while for liquid phase reaction the transportation of molecule is easier because the presence of solvents so the synthesis process is done at low temperature. There are three methods for Zeolite syntheses in the liquid phase are Hydrothermal method, Solvothermal method, and Ionothermal methods [167].

Comparison of several adsorbents based on the adsorption efficiency of metals. As we discuss above different adsorbents have various efficiency as well they have a different response for various metals. This can be summarizing in the table below [168-177] (Table 13 and 14)

\section{Nanostructured materials}

Nanostructured Materials are materials with a microstructure whose structural elements, clusters, crystallites, or molecules have dimensions of 1 to $100 \mathrm{~nm}$ range. A collection of distinguishable units in which the units are made of a limited number of atoms are Nanosized material. Their fundamental electrical, optical, and magnetic properties lead to a great interest in both academic and industrial levels over the past decade [178]. The properties of Nanostructured Materials differ from those of bulk materials with the same average chemical composition. This difference results from the reduced size and dimensionality of the Nano-sized materials. Nanomaterials properties make them deviate from the bulk materials, including high surface energy, a large fraction of surface atoms, reduced imperfections, and spatial confinement [179]

Table 13: Heavy metal removal using synthetic zeolite.

\begin{tabular}{|c|c|c|c|c|}
\hline $\mathbf{S / N}$ & Raw materials & $\begin{array}{c}\text { Type of metal } \\
\text { removed }\end{array}$ & $\mathbf{Q}$ (mg/g) & Reference \\
\hline $\mathbf{1}$ & Synthetic zeolite A & Cadmium & 315.65 & {$[168]$} \\
\hline $\mathbf{2}$ & Zeolite from fly ash & Cadmium & 195 & {$[169]$} \\
\hline $\mathbf{3}$ & Zeolite X & Cadmium & 92 & {$[170]$} \\
\hline $\mathbf{4}$ & Zeolite A & Copper & 41.6 & {$[160]$} \\
\hline $\mathbf{5}$ & Zeolite X & Zinc & 41 & {$[170]$} \\
\hline $\mathbf{6}$ & Zeolite A & Nickel & 24.65 & {$[160]$} \\
\hline $\mathbf{7}$ & Zeolite A & Lead & 213 & {$[160]$} \\
\hline
\end{tabular}

Table 14: Heavy metal removal using various adsorbent.

\begin{tabular}{|c|c|c|c|c|}
\hline $\mathbf{S} / \mathbf{N}$ & Type of materials & $\begin{array}{c}\text { Type of metal } \\
\text { removed }\end{array}$ & $\begin{array}{c}\text { Efficiency } \\
\text { (\%) }\end{array}$ & Reference \\
\hline $\mathbf{1}$ & Graphene oxide & chromium & $92.65 \%$ & {$[171]$} \\
\hline $\mathbf{2}$ & activated carbon & chromium & $84.8 \%$ & {$[172]$} \\
\hline $\mathbf{3}$ & Clay & Lead & $88 \%$ & {$[173]$} \\
\hline $\mathbf{4}$ & $\begin{array}{c}\text { Activated carbon } \\
\text { from olive stones }\end{array}$ & cadmium & $23 \%$ & {$[34]$} \\
\hline $\mathbf{5}$ & Eggshell & chromium & $93 \%$ & {$[65]$} \\
\hline $\mathbf{6}$ & Bottom ash & cadmium & $72.47 \%$ & {$[174]$} \\
\hline $\mathbf{7}$ & $\begin{array}{c}\text { Fly ash Modified by } \\
\text { Acetic acid }\end{array}$ & Copper & $60.07 \%$ & {$[175]$} \\
\hline $\mathbf{8}$ & $\begin{array}{c}\text { Zeolite from fly ash } \\
\text { Cadmium and } \\
\text { zinc }\end{array}$ & $95.6 \%$ & {$[169]$} \\
\hline $\mathbf{9}$ & Natural Zeolite & Copper & $99.86 \%$ & {$[176]$} \\
\hline $\mathbf{1 0}$ & $\begin{array}{c}\text { synthesis zeolite } \\
\text { using Silica Gel }\end{array}$ & Lead & 91.86 & {$[177]$} \\
\hline
\end{tabular}

The methods that are listed above which are Conventional materials have limitations of adsorption capacity and do not provide the desired removal efficiency for most treatments of heavy metals from wastewater due to the reason scientists perform research's to develop novel adsorbent with the best characteristic [180]. Nanomaterials are adsorbents that efficiently remove heavy metals from wastewater due to their enhanced active sites, high surface area, and the functional groups on their surface [181]. Certain areas including the removal of heavy metals from wastewater apply Nanomaterials because of their unique physical, chemical, and mechanical properties. Besides their high specific surface, these materials have very high strength, electrical conductivity, resistance, and thermal stability therefore they are used as effective adsorbents.

Types of nanoparticles: There are few naturally formed nanomaterials are occur which are from different bacteria types, volcanic eruptions, cosmic dust, and so on. Many man-made nanomaterials include fullerenes, graphene, carbon nanotubes, metal oxide nanorods, quantum dots, etc. [182]. There are different classes of Nanoparticles due to morphology, size, physical properties, and chemical properties. Some of them are carbon-based nanoparticles, metal nanoparticles, ceramic nanoparticles, semiconductor nanoparticles, polymeric nanoparticles, and lipid-based nanoparticles [179]. In this review paper, we will see only carbon-based nanoparticles and metal nanoparticles which are usually used in the adsorption of heavy metals from wastewater.

Carbon-based nanoparticles: Carbon-based nanoparticles include fullerenes, graphene, and carbon nanotubes.

Fullerenes: - Fullerenes are the allotropes of carbon represent closed cage of carbon molecules and the carbon units in these structures have a pentagonal and hexagonal arrangement. They were discovered in 1985 through spectrometric measurements its looks like hollow football and the structure of C-60 is called Buckminsterfullerene. their electrical conductivity, structure, high strength, and electron affinity lead them to have many commercial applications[183].

Fullerene's large specific surface area and the low tendency for aggregation make it interesting to apply them as adsorbents for the treatment of wastewater from the industry's [184]. These materials also extract different species from water because of its hydrophobic surface, high electron affinity, and high surface to volume ratio [185].

Graphene: - Graphene is a carbon-based is a two-dimensional, atomic-scale made from carbon atoms which were first invented in 2004. Like CNTs, it also has unique structural, mechanical, physical, and chemical properties that allow it to use in different fields [186].

Pristine graphene, graphene oxide, and reduced graphene oxide are the various forms in which graphene's available. To add hydrophilic groups for the removal of heavy metals graphene may be oxidized [187].

Recently the application of graphene and graphene-based materials is rapidly growing for environmental purposes including wastewater treatment because of their properties like enhanced active sites, high specific surface area, and the functional groups, and good chemical stability [181]. Researchers also confirmed that these materials have high sorption activity for the removal of heavy metals $[188,189]$.

Carbon nanotubes: - Carbon nanotubes are graphene sheets rolled into a tube they are 100 times stronger than steel so they are mainly used for structural reinforcement. these materials were invented in 1991 [190]. These materials are classified into single-walled carbon nanotubes and multi-walled carbon nanotubes [179]. Carbon 
nanotubes have a unique structure, semiconductor, mechanical, chemical electronic, optoelectronic, and physical properties which led research into a new area. They are efficient adsorbents for heavy metals due to the above properties combined with chemical stability, large specific surface area which is larger than fullerenes, and availability of well-developed mesoporous [191].

Metal nanoparticles: Metal nanoparticles are produced from metal precursors by chemical, electrochemical, or photochemical methods either from pure metals like silver, gold, platinum, iron, zinc, cerium, titanium, or their compounds such as oxides, hydroxides, phosphates, fluorides chlorides, and sulfides. Metal nanoparticles can adsorb small molecules so they are applicable in different research areas [179].

Metal Oxide nanoparticles: Metal elements can make a variety of compounds of oxides that can be used in different areas such as physics, chemistry, and material science. The goal in nanotechnology fields is to make nanomaterials with the special property which can adopt a variety of structural geometries with an electronic structure that can exhibit metallic, semiconductor, or insulator character. Due to their small size and high density of edge surfaces oxide nanoparticles have a unique physical and chemical property [192].

Properties of Metal Oxide nanoparticles: The physicochemical properties of nanomaterials are depending on their size which has special uses in chemistry. Many applications use nanomaterials directly related to their size dependence of oxide nanomaterials properties like mechanical, transport, electrical, optical, and surface chemistry [192].

Mechanical properties: - Low yield stress, hardness, and high super plasticity are the main concerns in mechanical properties. The mainly analyzed parameters are ductility, and super plasticity due to the lack of information Information on oxide nanomaterials [192].

Transport properties: - Metal oxide materials exhibit ionic or mixed ionic electronic conductivity. Both can affect by the nanostructure of the oxide this was experimentally defined and Boltzmann statics proposed that the number of electronic charge carriers is a function of bandgap energy [192].

Optical properties: - it is one of the most fundamental properties of metal oxides which can be obtained by reflectivity and absorption measurements experimentally [192].

Chemical properties: - In redox and acid/base properties oxides are essential for Absorption and Catalysis. There are three key important features for the application of absorbents the coordination environment of surface atoms, the redox properties, and the oxidation state at surface layers [192].

Among several metal oxide nanoparticles, some oxides classify as desirable materials for adsorption of heavy metals some of them are iron oxide, copper oxide, titanium oxide, magnesium oxide, cesium oxide, alumina oxide, and zinc oxide. The interesting and promising uses of the materials are due to their high selectivity and capacity to remove heavy metals from wastewater beside this property their size also helps them to penetrate the contamination zone were bulk materials cannot [193].

Opposing the whole advantages of metal oxide nanoparticles there is a problem reported due to the size reduction of metal oxides. The decrease in the size of metal oxide leads to poor stability because of the increase in surface energy [193]. The poor stability of particles leads to agglomeration due to Van der Waals forces or other interaction so the surface area would decrease thus high selectivity and efficiency to remove impurities will also decrease not only this the material may lose its mechanical strength [194-199] (Table 15).

Scientists have been work to improve the uses of metal oxide nanoparticles for removal of heavy metals from water and they suggest using those materials by emerging with other porous materials as a stabilizer or supporter to form nanocomposite adsorbent this overcome the limitations on the application of metallic oxide nanoparticles [193].

\section{Composite materials}

A material that is made up of two or more constituent materials with different chemical and physical properties then combined to make a single material that is varying from the individual material in the property. The use of metal oxide nanoparticles in water treatment is improved by combined using of the materials with alternative materials to overcome the limitations of those particles by using porous support materials as a matrix [200].

There are various matrixes which are used as a supporter for metal oxide nanomaterials but among those matrixes, zeolite is considered the best host and stabilizer because of its large surface area, hydrophilic, high ion exchange capacity, high thermal stability, tunable chemical properties, pores with $1.3 \mathrm{~nm}$ diameter, eco-friendly nature and inexpensive nature [193, 201]. Zeolite/Zinc Oxide Nanocomposite (Zeolite/ZnO NCs) was successfully synthesized by using a coprecipitation method for adsorption of Lead and Arsenic and get high adsorption capacity [193] and also magnetic nanocomposite of $\mathrm{Fe}_{3} \mathrm{O}_{4} /$ zeolite/cellulose nanofibers were synthesized for removal of zinc from water and the result shows the highest efficiency [202].

\section{Parameters affecting the adsorption process}

The efficiency of adsorbent in water purification is affected by many factors such as $\mathrm{Ph}$. Effect of agitation speed Value, temperature, the surface area of adsorbent, contact time, adsorbent dose, and initial concentration of impurity. The percent to remove heavy metals from aqueous solution is increased by increasing those factors that are listed above [193,202-206] (Table 16).

\section{Initial concentration of impurity}

As the initial concentration of heavy metals increases the adsorbed heavy metals are increased due to the formation of gradient concentration between aqueous solution and adsorbent surface this render to effective interaction of adsorbent and impurity [202,207]. This phenomenon is shown in the graph below for the removal of lead and arsenic as the concentration increases the adsorption capacity also increases [208] (Figure 7).

Table 15: Heavy metal removal using metal oxide nanoparticles.

\begin{tabular}{|c|c|c|c|c|}
\hline$S / N$ & Raw materials & $\begin{array}{l}\text { Type of metal } \\
\text { removed }\end{array}$ & $\mathrm{Q}(\mathrm{mg} / \mathrm{g})$ & Reference \\
\hline 1 & $\mathrm{ZnO}$ & Lead & 6.7 & [195] \\
\hline 2 & $\mathrm{TiO}_{2}$ & $\begin{array}{c}\text { Zinc } \\
\text { Cadmium }\end{array}$ & $\begin{array}{l}15.3 \\
7.9\end{array}$ & [196] \\
\hline 3 & $\alpha-\mathrm{Fe}_{2} \mathrm{O}_{3}$ & Copper & 84.46 & [197] \\
\hline 4 & $\mathrm{~V}-\mathrm{Al}_{2} \mathrm{O}_{3}$ & Nickel & 176.1 & [198] \\
\hline 5 & $\alpha-\mathrm{FeOOH}$ & Copper & 149.25 & [197] \\
\hline 6 & $\mathrm{CeO}_{2}$ & Chromium & 121.95 & [199] \\
\hline
\end{tabular}


Other publication also shows the increase in adsorption capacity because more metal ion can be absorbed as the initial concentration of metal increases [209]. The study was conducted on the removal of $\mathrm{Zn}^{+2}$ and the obtained result for the initial concentration of zinc is almost the same that we have seen before the only difference here is it reaches a maximum at $3 \mathrm{ppm}$ (Figure 8).

\section{Contact time}

Adsorption efficiency is rapidly increased at the first in the adsorption process and then a slow improvement occurs at a constant rate this is due to the empty adsorbent surface at the initial stage of the process so molecules adsorb rapidly. However, as time goes the adsorption process shows no change due to the saturation of the adsorbent surface. This effect can be elaborate by using some results obtained in different works [202,209] (Figure 9 and 10).

\section{Effect of agitation speed}

Adsorbent capacity firstly increased as the increased in agitation speed because at first the mass transfer of the adsorbate from the bulk solution to a hydrodynamic layer surrounding the adsorbent particles which result in greater efficiency and adsorbent capacity and then become constant because of the thickness of the hydrodynamic layer decreases to some degree [210]. Here we can

Table 16: Heavy metal removal using composite materials.

\begin{tabular}{|c|c|c|c|c|}
\hline S/N & Raw materials & $\begin{array}{c}\text { Type of metal } \\
\text { removed }\end{array}$ & $\mathbf{Q}$ (mg/g) & Reference \\
\hline $\mathbf{1}$ & G-MgAl-LDH & Chromium & 172.55 & {$[203]$} \\
\hline $\mathbf{2}$ & GO-NH $_{2}$ & Cobalt & 116.35 & {$[204]$} \\
\hline $\mathbf{3}$ & SAGO aerogel & Lead & 267.4 & {$[205]$} \\
\hline $\mathbf{4}$ & G-nZVI & Chromium & 162 & {$[206]$} \\
\hline $\mathbf{5}$ & $\mathrm{Fe}_{3} \mathrm{O}_{4} /$ zeolite/cellulose & Zinc & 9.45 & {$[171]$} \\
\hline $\mathbf{6}$ & Zeolite and ZnO & Lead & 24.5 & {$[162]$} \\
\hline
\end{tabular}

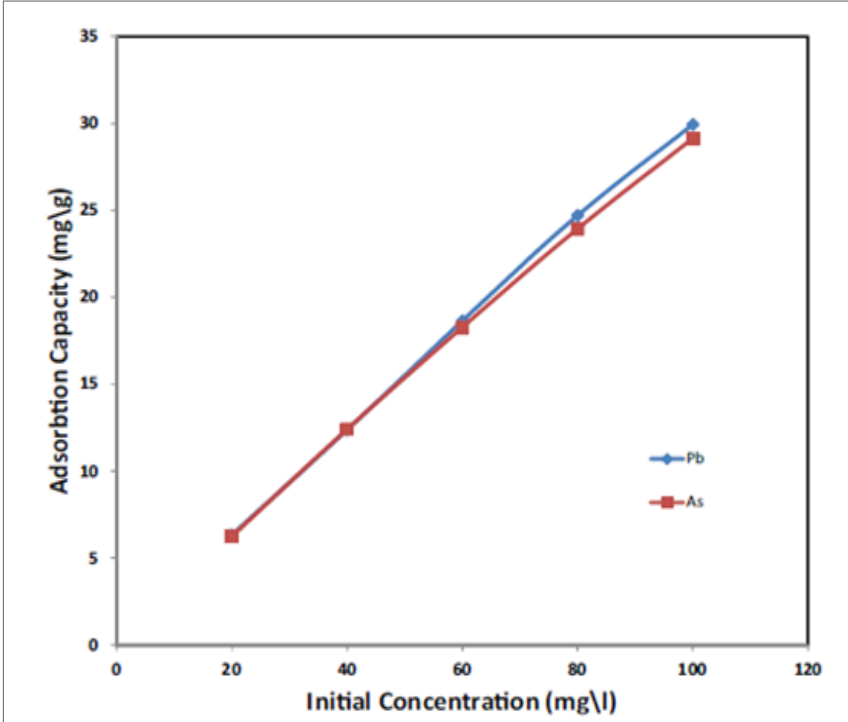

Figure 7: Effect of initial Lead and Arsenic concentration on the adsorption capacity [208].

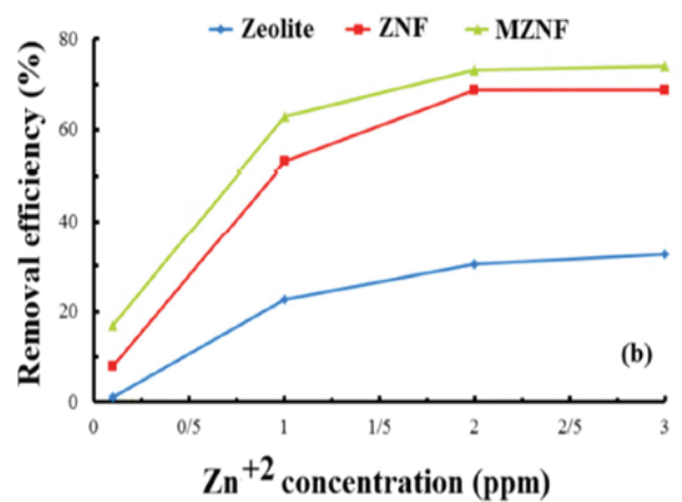

Figure 8: The effect of initial $Z n+2$ concentration [209].

see the published result which is conduct for removal of zinc ion from wastewater (Figure 11).

\section{PH value}

At low ph. value which is highly acidic hydrogen ion competes with metal ions to occupy the sites of the adsorbent [211] and also at high $\mathrm{ph}$. the value which is a high alkali region there is the generation of more hydroxyl sites which also decreases the adsorption efficiency [212]. Better information can be obtained from the graphs below those results are conducted for different metals by different Nanocomposites (Figure 12 and 13).

\section{Temperature}

As many studies show that the efficiency adsorption process and temperature are proportional. As temperature increases the mobility of metal ions increases which increases the probability to find an empty site on the absorbent this leads to an increase in adsorption capacity. [202,213]. The effect of temperature on the removal efficiency of zinc ions is shown in the obtained result of the graph below (Figure 14).

\section{Dosage of adsorbent}

An increase in adsorption leads to an increase in adsorption capacity due to the larger surface area and more adsorption sites formation as a result more heavy metals can be attached to the adsorbent [214]. After reaching the maximum efficiency the removal efficiency will decrease due to aggregation of adsorbent which leads to a decrease in the surface is $[215,216]$ a published result below shows the phenomena of adsorbent dosage on the efficiency of adsorption (Figure 15 and 16).

\section{Specific surface area (SSA) of the adsorbent}

The higher surface area formed a porous layer on the surface and in the channel of the adsorbent structural thus the adsorbent with a large surface area provides a large number of functional groups that enhance the adsorption process [217,218] (Figure 17 and 18).

In the study, the performance was assessed by comparisons on adsorption capacities of differently modified nanoparticles on different heavy metal ions $(\mathrm{Cu}, \mathrm{Cd}, \mathrm{Co}, \mathrm{Ni}, \mathrm{Pb}, \mathrm{As}, \mathrm{Cr}, \mathrm{Zn}, \mathrm{Mn}$, and $\mathrm{Hg})$. As shown in the above figure a general increase in adsorption capacity due to an increase in a specific area with the introduction of multifunctional group materials [219]. 


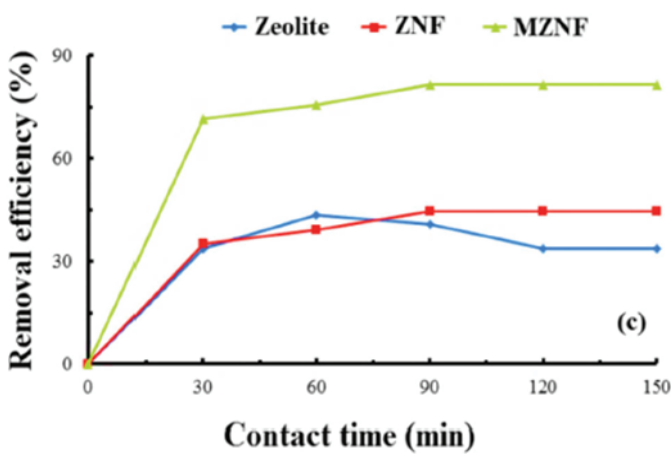

Figure 9: The Effect of contact time on removal efficiency of zinc [209].

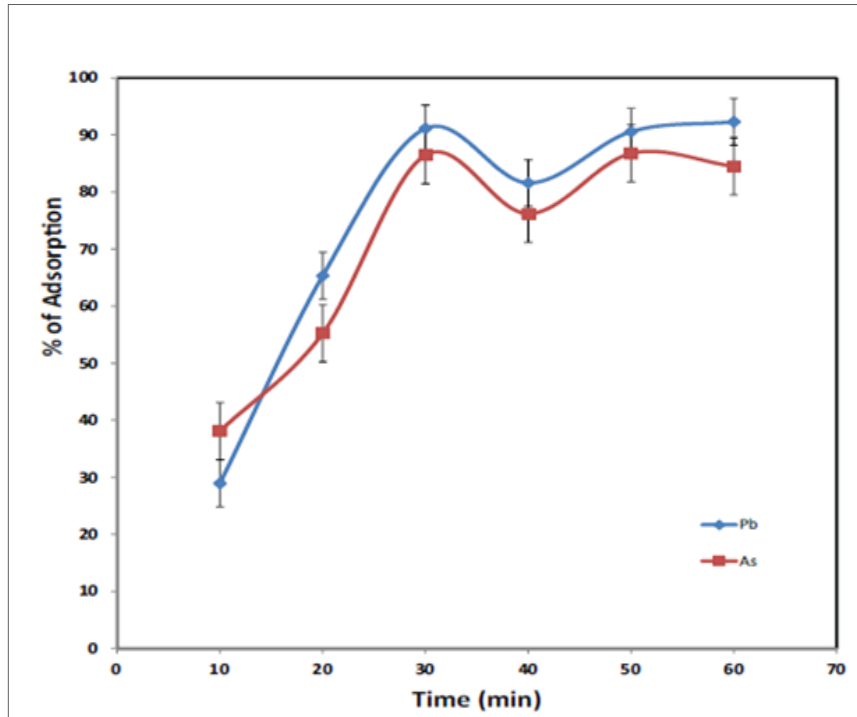

Figure 10: The Effect of contact time on the percentage of removal of lead and Arsenic [208].

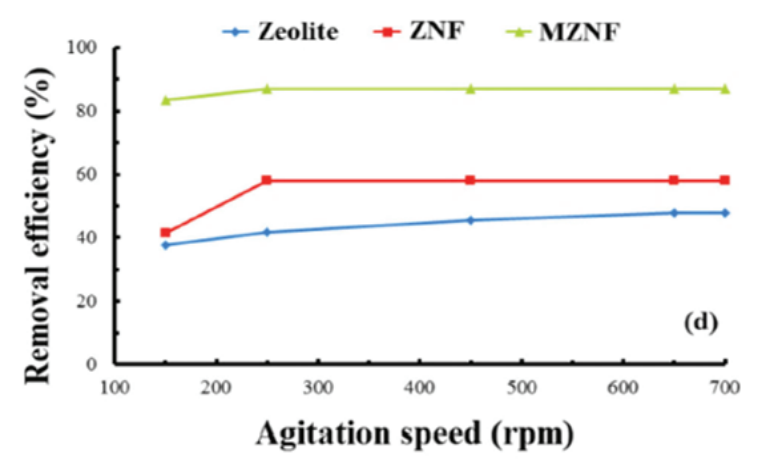

Figure 11: The effect of agitation speed on the removal efficiency of $\mathrm{Zn}^{+2}$ ions [209].

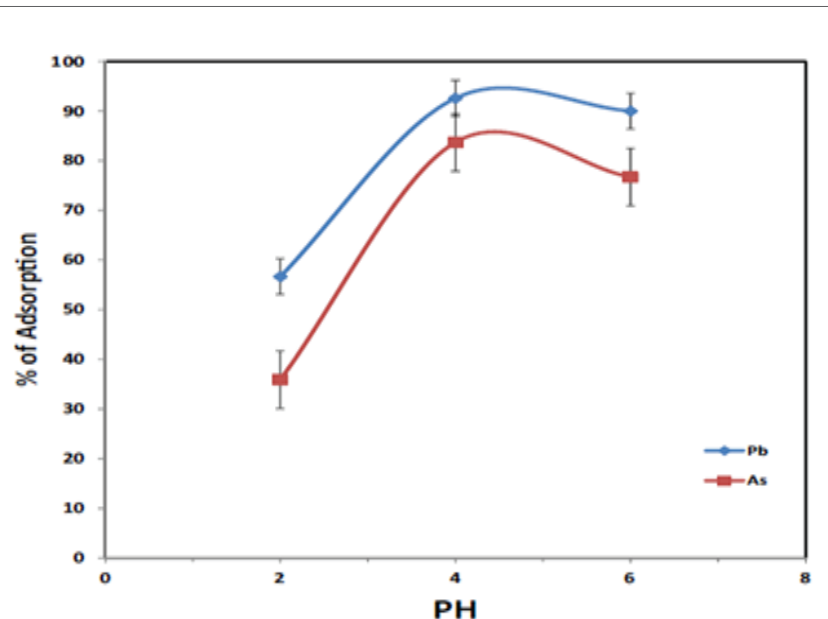

Figure 12: Effect of $\mathrm{pH}$ solution on the percentage adsorption of lead and Arsenic [208].

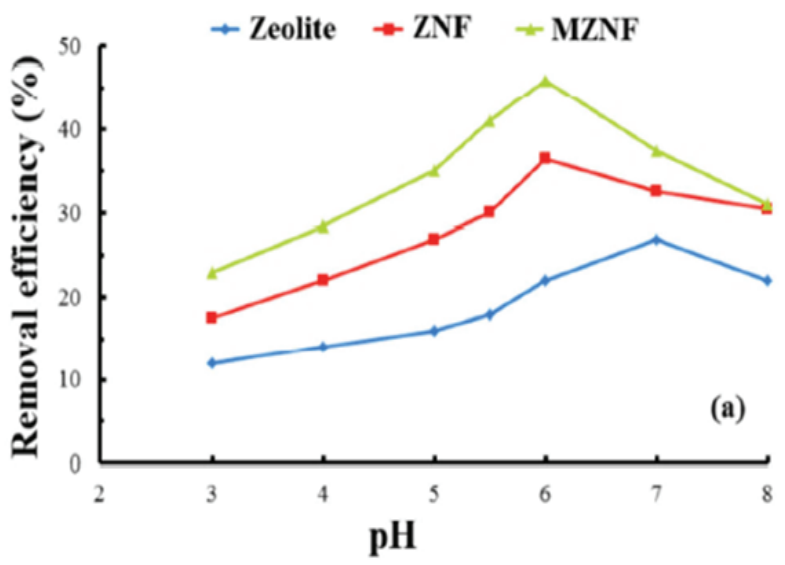

Figure 13: The effect of $\mathrm{pH}$ on the removal efficiency of $\mathrm{Zn+2}$ ions [209].

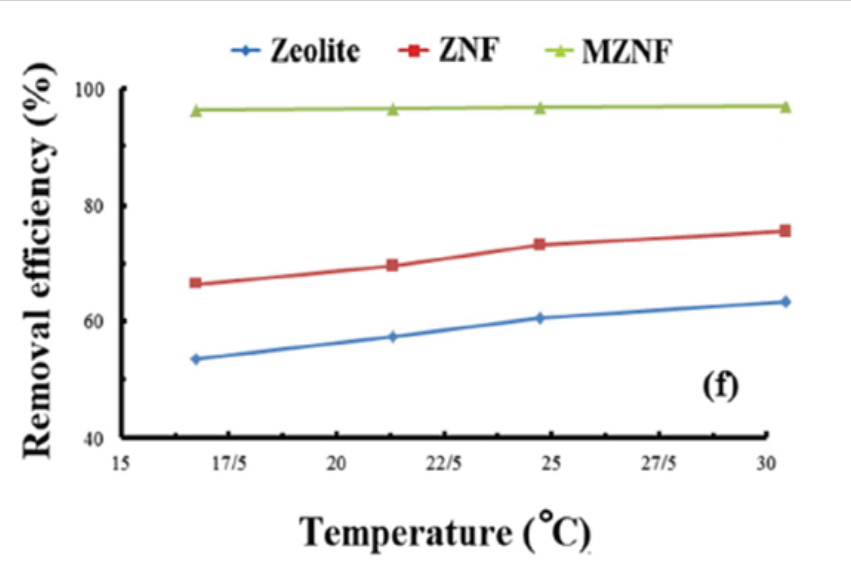

Figure 14: The effect of $\mathrm{pH}$ on the removal efficiency of $\mathrm{Zn+2}$ ions [209]. 


\section{Conclusion}

In the recent paper, detailed information for conventional and nanostructured materials in adsorption was discussed. The main focus of the paper was to show promising adsorbents like zeolites, metal oxide nanoparticles, and composite materials in the adsorption process. In this regard, Nano based materials have a unique physical, chemical, and mechanical property which makes them promising adsorbents. In converse to those advantages, there is a problem of agglomeration as the size of the materials decreases to Nanosized level due to the poor stability of the particles. To overcome this barrier scientists start to use a porous material with a high surface area as a supporter and engaged them with the nanostructure materials and obtained a successful result that opens away for future researches. From several works that are conducted on this is some of them are reviewed in this review paper and show away to study more.

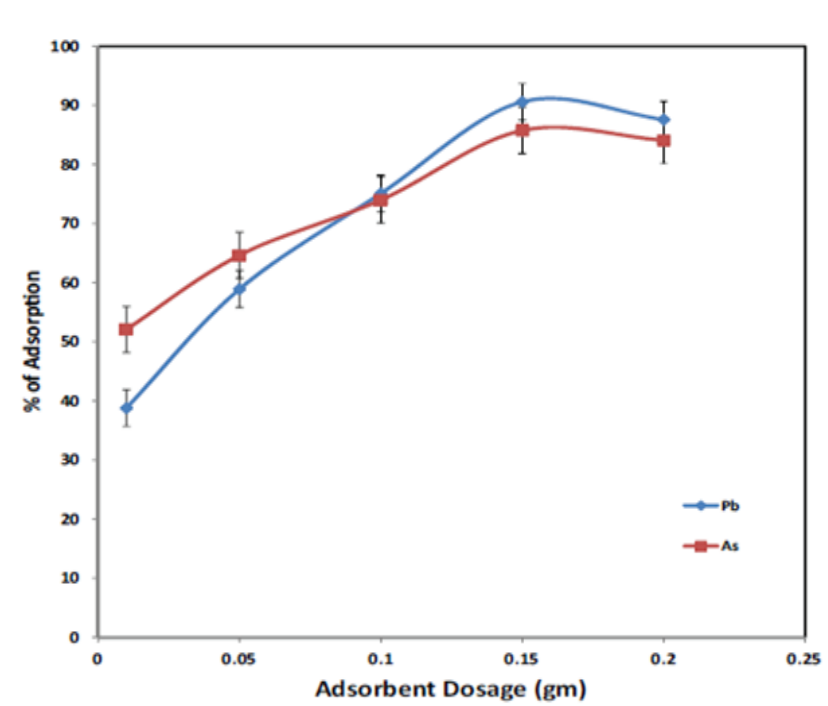

Figure 15: Effect of adsorbent dosage on the percentage adsorption of lead and Arsenic [208].

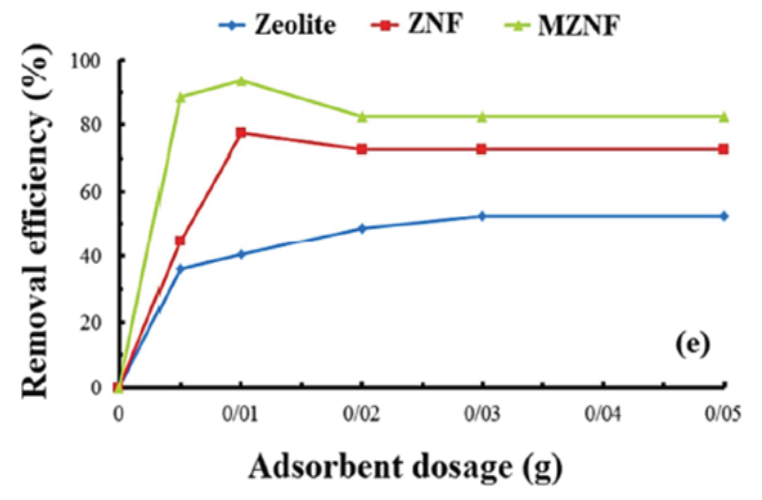

Figure 16: The effect of adsorbent dosage on the removal efficiency of $Z n+2$ ions [209]

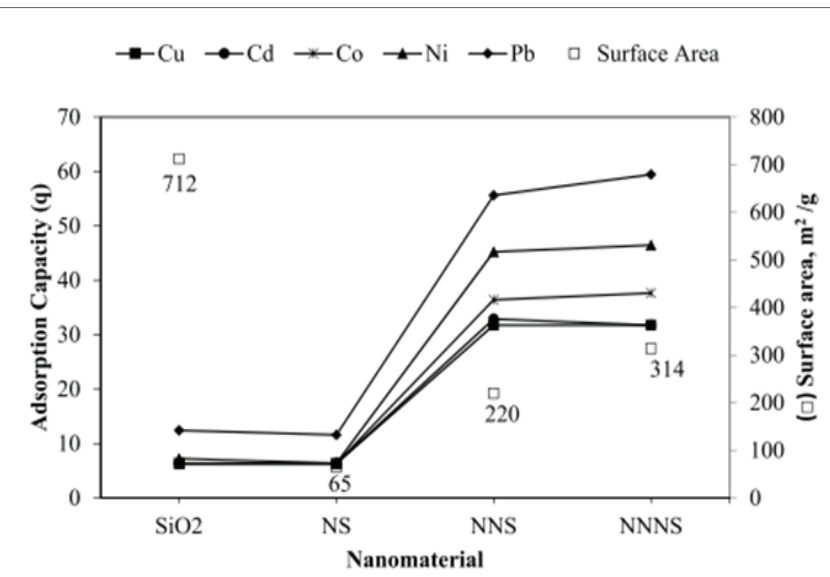

Figure 17: Comparison of adsorption capacities of naked and modified silica nanoparticles [219].

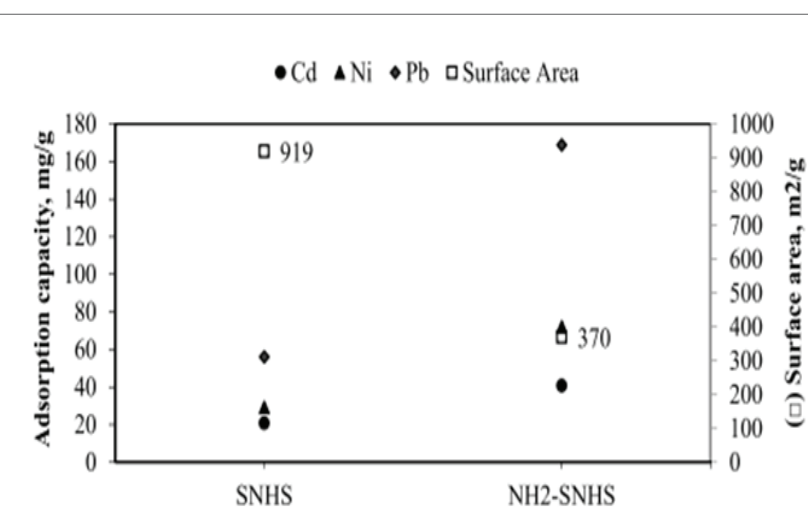

Figure 18: The behavior of the specific surface area and adsorption capacity with surface modification for silica nano hollow spheres [219].

\section{References}

1. Paul D (2017) Research on heavy metal pollution of river Ganga: A review. Ann Agrar Sci 15: 278-286.

2. Visa M, Popa N (2015) Adsorption of Heavy Metals Cations onto Zeolite Material from Aqueous Solution. J Membr Sci Technol 5: 133.

3. Visa M (2016) Synthesis and characterization of new zeolite materials obtained from fly ash for heavy metals removal in advanced wastewater treatment. Powder Technology 294: 338-347.

4. Mosby C, Glanze W, Anderson K (1996) Mosby Medical Encyclopedia, The Signet: Revised Edition. St. Louis 16: 875-882.

5. Jaishankar M, Tseten T, Anbalagan N, Mathew BB, Beeregowda KN (2014) Toxicity, mechanism and health effects of some heavy metals. Interdiscip Toxicol 7: 60-72.

6. Mosisa MT (2017) Effect of processing on proximate and mineral composition of black climbing (P. coccineus L.) bean flour. African journal of food science 3: 74-78.

7. Wang LK, Vaccari DA, LiY, Shammas NK (2005) Chemical precipitation. Physicochemical Treatment Processes 3: 141-197. 
8. Nachod FC (2012) Ion exchange: theory and application. Elsevier.

9. Rashed IG, Hanna MA, El-Gamal HF, Al-Sarawy AA, Wali FKM (2005) Overview on Chemical Oxidation Technology in Wastewater Treatment. Ninth International Water Technology Conference IWTC9.

10. Amjad Z (1993) Reverse osmosis: membrane technology, water chemistry, and industrial Applications. Van Nostrand Reinhold New York.

11. Cheryan M (1986) Ultrafiltration handbook. Taylor \& Francis, University of Michigan.

12. Mohammadi T, Moheb A, Sadrzadeh M, Razmia B (2005) Modeling of metal ion removal from wastewater by electrodialysis. Sep Purif Technol 41: 73-82.

13. Fu F, Wang $Q$ (2011) Removal of heavy metal ions from wastewaters: a review. Journal of environmental management 92: 407-418.

14. Cooney DO (1998) Adsorption design for wastewater treatment. CRC press.

15. Renu, Agarwal $M$, Singh $K$ (2017) Heavy metal removal from wastewater using various adsorbents: a review. Journal of Water Reuse and Desalination 7: 387-419.

16. Burakov AE, Galunin EV, Burakova IV, Kucherova AE, Agarwal $S$, et al. (2018) Adsorption of heavy metals on conventional and nanostructured materials for wastewater treatment purposes: A review. Ecotoxicol Environ Saf 148: 702-712.

17. Suhas, Gupta VK, Carrott PJM, Singh R, Chaudhary M, et al. (2016) Cellulose: a review as natural, modified and activated carbon adsorbent. Bioresource technology 216: 1066-1076.

18. Tripathi A, Ranjan MR (2015) Heavy metal removal from wastewater using low cost adsorbents. J Bioremed Biodeg 6: 315.

19. Kast W (1988) Adsorption aus der Gasphase Ingenieurwissenschaftliche Grundlagen und technische Verfahren. Wiley-VCH Verlag GmbH.

20. Jin-Fen P, Rong-Gen L, Li M (2000) A review of heavy metal adsorption by marine algae. J Oceanol Limnol 18: 260-264.

21. Wang J, Guo X (2020) Adsorption isotherm models Classification physical meaning application and solving. Chemosphere 258: 127279.

22. Burakov $A E$, Galunin EV, Burakova IV, Kucherova $A E$, Agarwal $S$, et al. (2018) Adsorption of heavy metals on conventional and nanostructured materials for wastewater treatment purposes: A review. Ecotoxicol Environ Saf 148: 702-712.

23. Crini G, Lichtfouse E, Wilson LD, Morin-Crini N (2019) Conventional and non-conventional adsorbents for wastewater treatment. Environmental Chemistry Letters 17: 195-213.

24. Marsh H, Reinoso FR (2006) Activated carbon. $1^{\text {st }}$ Edition, Elsevier Science.

25. Peláez-Cid AA, Teutli-León MMM (2012) Lignocellulosic Precursors Used in the Elaboration of Activated Carbon-Characterization Techniques and Applications in the Wastewater Treatment.

26. Nabais JV, Carrott R, Carrott MMLR, Luz V, Ortiz AL (2008) Influence of preparation conditions in the textural and chemical properties of activated carbons from a novel biomass precursor: the coffee endocarp. Bioresour Technol 99: 7224-7231.
27. Anirudhan TS, Sreekumari SS (2011) Adsorptive removal of heavy metal ions from industrial effluents using activated carbon derived from waste coconut buttons. J Environ Sci 23: 1989-1998.

28. Gueye M, Richardson Y, Kafack FT, Blinab J (2014) High efficiency activated carbons from African biomass residues for the removal of chromium (VI) from wastewater. J Environ Chem Eng 2: 273-281.

29. Arulkumar M, Thirumalai K, Sathishkumar P, Palvannan T (2012) Rapid removal of chromium from aqueous solution using novel prawn shell activated carbon. Chem Eng J 185: 178-186.

30. Bernard E, Jimoh A, Odigure J (2013) Heavy metals removal from industrial wastewater by activated carbon prepared from coconut shell. Res J Chem Sci 2231: 606X.

31. El Nemr A, El-Sikaily A, Khaled A, Abdelwahab O (2015) Removal of toxic chromium from aqueous solution, wastewater and saline water by marine red alga Pterocladia capillacea and its activated carbon. Arabian Journal of Chemistry 8: 105-117.

32. Ozer A, Tumen F (2003) Cd(II) adsorption from aqueous solution by activated carbon from sugar beet pulp impregnated with phosphoric acid. Fresenius Environmental Bulletin 12: 1050-1058.

33. Andrew OE, Olushola AA, Opeoluwa OG, Dada WO (2014) Detoxification of chromium (vi) ions in aqueous solution via adsorption by raw and activated carbon prepared from sugarcane waste. Covenant Journal of Physical and Life Sciences 2.

34. Bohli T, Ouederni A, Fiol N, Villaescusa I (2015) Evaluation of an activated carbon from olive stones used as an adsorbent for heavy metal removal from aqueous phases. Chemicals Reports 18: 88-99.

35. Mohan D, Singh KP, Singh VK (2006) Trivalent chromium removal from wastewater using low cost activated carbon derived from agricultural waste material and activated carbon fabric cloth. J Hazard Mater 135: 280-295.

36. Mathew BB, Jaishankar M, Biju VG, Beeregowda KN (2016) Role of bioadsorbents in reducing toxic metals. J Toxicol.

37. Shaker MA, Hussein HM (2005) Heavy-metal adsorption by nonliving biomass. Chemistry and Ecology 21: 303-311.

38. The biology of the Saccharum spp. (Sugarcane) 2011.

39. Ngah WSW. Hanafiah MAKM (2008) Removal of heavy metal ions from wastewater by chemically modified plant wastes as adsorbents: a review. Bioresour Technol 99: 3935-3948.

40. Palin D Jr, Rufato KB, Linde GA, Colauto NB, Caetano J, et al. (2016) Evaluation of $\mathrm{Pb}$ (II) biosorption utilizing sugarcane bagasse colonized by Basidiomycetes. Environ Monit Assess 188: 279.

41. Khoramzadeh E, Nasernejad B, Halladj R (2013) Mercury biosorption from aqueous solutions by sugarcane bagasse. J Taiwan Inst Chem Eng 44: 266-269.

42. Jiang $\mathrm{Y}$, Pang $\mathrm{H}$, Liao B (2009) Removal of copper (II) ions from aqueous solution by modified bagasse. Journal of Hazardous Materials 164: 1-9.

43. Ibrahim SC, Hanafiah MAKM, Yahya MZA (2006) Removal of cadmium from aqueous solutions by adsorption onto sugarcane bagasse. Am Eurasian J Agric Environ Sci 1: 179-184.

44. Kong W, Ren J, Wang S, Chen Q (2014) Removal of heavy metals from aqueous solutions using acrylic-modified sugarcane bagassebased adsorbents: equilibrium and kinetic studies. BioResources 9: 3184-3196. 
45. Karnitz O Jr, Gurgel LVA, de Freitas RP, Gila LF (2009) Adsorption of $\mathrm{Cu}$ (II), $\mathrm{Cd}$ (II), and $\mathrm{Pb}$ (II) from aqueous single metal solutions by mercerized cellulose and mercerized sugarcane bagasse chemically modified with EDTA dianhydride (EDTAD). Carbohydrate Polymers 77: 643-650.

46. Singh R (2009) 5-Fluoro-4N-phenyl-4-pyrimidineamine compounds. Google Patents.

47. Ravat C, Dumonceau J, Monteil-Rivera F (2000) Acid/base and Cu (II) binding properties of natural organic matter extracted from wheat bran: modeling by the surface complexation model. Water Research 34: 1327-1339.

48. Farajzadeh MA, Monji AB (2004) Adsorption characteristics of wheat bran towards heavy metal cations. Separation and Purification Technology 38: 197-207.

49. Özer A, Özer D (2004) The adsorption of $\mathrm{Cr}(\mathrm{VI})$ on sulphuric acidtreated wheat bran. Environ Technol 25: 689-697.

50. Kaya K, Pehlivan E, Schmidt C, Bahadir M (2014) Use of modified wheat bran for the removal of chromium (VI) from aqueous solutions. Food chemistry 158: 112-117.

51. Ingole NW, Patil VN (2013) Cadmium removal from aqueous solution by modified low cost adsorbent (s): A state of the art. Research and Development (IJCSEIERD) 3: 17-26.

52. Namasivayam C, Sureshkumar MV (2008) Removal of chromium (VI) from water and wastewater using surfactant modified coconut coir pith as a biosorbent. Bioresour technol 99: 2218-2225.

53. Raghavi MD, Sakthi Balaa M, Surender S, Lokesh P, Kalidas K (2019) Review on Area, Production and Productivity of Coconut in India. International Journal of Research in Business Management 7: 1-6.

54. Berridge MV, Tan AS (1993) Characterization of the cellular reduction of 3-(4,5-dimethylthiazol-2-yl)-2, 5-diphenyltetrazolium bromide (MTT): subcellular localization, substrate dependence, and involvement of mitochondrial electron transport in MTT reduction. Arch Biochem Biophys 303: 474-482.

55. Ahmad R, Hasany SM, Chaudhary MH (2005) Adsorption Characteristics of $\mathrm{Cr}$ (III) ions onto Coconut Husk from Aqueous Solution. Adsorption Science \& Technology 23: 467-477.

56. Unnithan MR, Vinod VP, Anirudhan T (2004) Synthesis, Characterization, and Application as a Chromium (VI) Adsorbent of Amine-Modified Polyacrylamide-Grafted Coconut Coir Pith. Industrial \& Engineering Chemistry Research 43: 2247-2255.

57. Babel S, Kurniawan TA (2004) $\mathrm{Cr}(\mathrm{VI})$ removal from synthetic wastewater using coconut shell charcoal and commercia activated carbon modified with oxidizing agents and/or chitosan. Chemosphere 54: 951-967.

58. Kadirvelu K, Namasivayam C (2003) Activated carbon from coconut coirpith as metal adsorbent: adsorption of $\mathrm{Cd}$ (II) from aqueous solution. Advances in Environmental Research 7: 471-478.

59. Sekar M, Sakthi V, Rengaraj S (2004) Kinetics and equilibrium adsorption study of lead(II) onto activated carbon prepared from coconut shell. J Colloid Interface Sci 279: 307-313.

60. Parab H, Joshi S, Shenoy N, Lali A, Sarma US, et al. (2006) Determination of kinetic and equilibrium parameters of the batch adsorption of $\mathrm{Co}$ (II), $\mathrm{Cr}$ (III) and Ni (II) onto coir pith. Process Biochemistry 41: 609-615.

61. Zaheer K (2015) An Updated Review on Chicken Eggs. Production, Consumption, Management Aspects and Nutritional Benefits to Human Health. Food and Nutrition Sciences 6: 1208-1220.
62. Toro P, Quijada R, Yazdani-Pedram M, Arias JL (2007) Eggshell, a new bio-filler for polypropylene composites. Materials letters 61: 43474350.

63. Guru PS, Dash S (2013) Amino acid modified eggshell powder (AA-ESP)-A novel bio-solid scaffold for adsorption of some Styrylpyridinium dyes. J disper sci technol 34: 1099-1112.

64. Rohim R, Ahmad R, Ibrahim N, Hamidin N, Zulzikrami Azner Abidin C (2014) Characterization of Calcium Oxide Catalyst from Eggshell Waste. Adv Environ Biol 8: 35-38.

65. Elabbas S, Mandi L, Berrekhis F, Noelle Pons M, Pierre Leclerc J, et al. (2016) Removal of $\mathrm{Cr}(\mathrm{III})$ from chrome tanning wastewater by adsorption using two natural carbonaceous materials: Eggshell and powdered marble. J Environ Manage 166: 589-595.

66. Chojnacka K (2005) Biosorption of Cr (III) ions by eggshells. J Hazard Mater 121: 167-173.

67. Ahmad R, Kumar R, Haseeb S (2012) Adsorption of $\mathrm{Cu}^{2+}$ from aqueous solution onto iron oxide coated eggshell powder: Evaluation of equilibrium, isotherms, kinetics, and regeneration capacity. Arabian Journal of Chemistry 5: 353-359.

68. Chen D, Xiao X, Yang K (2016) Removal of phosphate and hexavalent chromium from aqueous solutions by engineered waste eggshell. RSC advances 6: 35332-35339.

69. Liu B, Huang Y (2011) Polyethyleneimine modified eggshell membrane as a novel biosorbent for adsorption and detoxification of $\mathrm{Cr}(\mathrm{VI})$ from water. Journal of Materials Chemistry 21: 1741317418.

70. Argun, ME, Dursun S, Ozdemir C, Karatas M (2007) Heavy metal adsorption by modified oak sawdust: Thermodynamics and kinetics. J Hazard Mater 141: 77-85.

71. Shukla A, Zhang Y-H, Dubey P, Margrave JL, Shukla SS (2002) The role of sawdust in the removal of unwanted materials from water. $J$ Hazard Mater 95: 137-152.

72. Memon SQ, Memon N, Shah SW, Khuhawar MY, Bhanger MI (2007) Sawdust-A green and economical sorbent for the removal of cadmium (II) ions. J Hazard Mater 139: 116-121.

73. Ur-Rehman H, Shakirullah M, Ahmad I, Shah S, Hameedullah (2006) Sorption studies of nickel ions onto sawdust of Dalbergia sissoo. Journal of the Chinese Chemical Society 53: 1045-1052.

74. Gupta S, Babu BV (2009) Removal of toxic metal $\mathrm{Cr}(\mathrm{VI})$ from aqueous solutions using sawdust as adsorbent: Equilibrium, kinetics and regeneration studies. Chemical Engineering Journal 150: 352-365.

75. Acar FN, Eren Z, (2006) Removal of $\mathrm{Cu}(\mathrm{II})$ ions by activated poplar sawdust (Samsun clone) from aqueous solutions. J Hazard Mater 137: 909-914.

76. Taty-Costodes VC, Fauduet H, Porte C, Delacroix A (2003) Removal of $\mathrm{Cd}(\mathrm{II})$ and $\mathrm{Pb}$ (II) ions, from aqueous solutions, by adsorption onto sawdust of Pinus sy/vestris. J Hazard Mater 105: 121-142.

77. Shukla SR, Pai RS (2005) Adsorption of Cu (II), Ni (II) and Zn (II) on dye loaded groundnut shells and sawdust. Separation and purification Technology 43: 1-8.

78. Rahman, IA, Ismail J, Osman H (1997) Effect of nitric acid digestion on organic materials and silica in rice husk. Journal of Materials Chemistry 7: 1505-1509. 
79. Chuah, TG, Jumasiah A, Azni I, Katayon S, Thomas Choong SY (2005) Rice Husk as A Potentially Low-Cost Biosorbent for Heavy Metal and Dye Removal: An Overview. Desalination 175: 305-316.

80. Oladoja NA, Ololade IA, Alimi OA, Akinnifesi TA, Olaremu GA (2013) Iron incorporated rice husk silica as a sorbent for hexavalent chromium attenuation in aqueous system. Chemical Engineering Research and Design 91: 2691-2702.

81. Kumar U, Bandyopadhyay M (2006) Fixed bed column study for $\mathrm{Cd}$ (II) removal from wastewater using treated rice husk. J. Hazard. Mater 129: 253-259.

82. Sugashini S, Begum KMMS (2015) Preparation of activated carbon from carbonized rice husk by ozone activation for $\mathrm{Cr}(\mathrm{VI})$ removal. New carbon materials 30: 252-261.

83. Wong KK, Lee CK, Low KS, Haron MJ (2003) Removal of Cu and $\mathrm{Pb}$ by tartaric acid modified rice husk from aqueous solutions. Chemosphere 50: 23-28.

84. Rosen MJ, Kunjappu JT (2012) Surfactants and interfacial phenomena. John Wiley \& Sons.

85. Nadeem M, Shabbir M, Abdullah MA, Shah SS, Mckay G (2009) Sorption of cadmium from aqueous solution by surfactant-modified carbon adsorbents. Chem Eng J 148: 365-370.

86. Min Y, Zhang M, Liu B, Xu X, Li X, et al. (2013) Characteristics of amine surfactant modified peanut shell and its sorption property for $\mathrm{Cr}(\mathrm{VI})$. Chin J Chem Eng 21: 1260-1268.

87. Hoek C, Van den HC, Mann D, Jahns HM, Jahns M (1995) Algae: an introduction to phycology. Cambridge university press.

88. Bird MI, Wurster CM, Silva PHD, Paul NA, De Nys R (2011) Algal biochar: effects and applications. Gcb Bioenergy 4: 61-69.

89. Apiratikul R, Pavasant P (2008) Batch and column studies of biosorption of heavy metals by Caulerpa lentillifera. Bioresour technol 99: 2766-2777.

90. Romera E, Gonzalez F, Ballester A, Blázquez ML, Munoz JA (2007) Comparative study of biosorption of heavy metals using different types of algae. Bioresour technol 98: 3344-3353.

91. Diaz-Pulido G, McCook LJ (2008) Environmental Status: Macroalgae (Seaweeds).

92. Khan MI, Shin JH, Kim JD (2018) The promising future of microalgae: current status, challenges, and optimization of a sustainable and renewable industry for biofuels, feed, and other products. Microb Cell Fact 17: 36.

93. Raja R, Shanmugam H, Ganesan V, Carvalho IS (2014) Biomass from Microalgae An Overview. J Oceanogr Mar Sci 2:1.

94. Phukan MM (2014) Biomass and biofuel characterization of some microalgal species of Assam.

95. Valdman E, Leite SGF (2000) Biosorption of $\mathrm{Cd}, \mathrm{Zn}$ and $\mathrm{Cu}$ by Sargassum sp. waste biomass. Bioprocess Eng 22: 171-173.

96. Incharoensakdi A, Kitjaharn P (2002) Zinc biosorption from aqueous solution by a halotolerant cyanobacterium Aphanothece halophytica. Curr Microbiol 45: 261-264.

97. Bakkaloglu I, Butter TJ, Evison LM, Holland FS, Hancockt IC (1998) Screening of various types biomass for removal and recovery of heavy metals $(\mathrm{Zn}, \mathrm{Cu}, \mathrm{Ni})$ by biosorption, sedimentation and desorption. Water sci technol 38: 269-277.
98. Holan ZR, Volesky B, Prasetyo I (1993) Biosorption of cadmium by biomass of marine algae. Biotechnol bioeng 41: 819-825.

99. Herrero R, Lodeiro P, García-Casal LJ, Vilariño T, Rey-Castro C, et al. (2011) Full description of copper uptake by algal biomass combining an equilibrium NICA model with a kinetic intraparticle diffusion driving force approach. Bioresour technol 102: 2990-2997.

100. Christoforidis AK, Orfanidis S, Papageorgiou SK, Lazaridou AN, Favvas Ep, et al. (2015) Study of Cu (II) removal by Cystoseira crinitophylla biomass in batch and continuous flow biosorption. Chem Eng J 277: 334-340.

101. Aksu Z, Balibek E (2007) Chromium (VI) biosorption by dried Rhizopus arrhizus: effect of salt $(\mathrm{NaCl})$ concentration on equilibrium and kinetic parameters. J Hazard mater 145: 210-220.

102. Tsekova K, Todorova D, Ganeva S (2010) Removal of heavy metals from industrial wastewater by free and immobilized cells of Aspergillus niger. Int Biodeterior Biodegradation 64: 447-451.

103. Bayramoğlu G, Arıca MY (2008) Removal of heavy mercury (II), cadmium (II) and zinc (II) metal ions by live and heat inactivated Lentinus edodes pellets. Chem Eng J 143: 133-140.

104. Bhainsa KC, D'souza SF (2008) Removal of copper ions by the filamentous fungus, Rhizopus oryzae from aqueous solution. Bioresour Technol 99: 3829-3835.

105. Mann H (1990) Biosorption of heavy metals by bacterial biomass, in Biosorption of heavy metals. CRC Press Boca Raton FL: 93-137.

106. Uslu G, Tanyol M (2006) Equilibrium and thermodynamic parameters of single and binary mixture biosorption of lead (II) and copper (II) ions onto Pseudomonas putida: effect of temperature. J Hazard Mater 135: 87-93.

107. Veglio F, Beolchini F (1997) Removal of metals by biosorption: a review. Hydrometallurgy 44: 301-316.

108. Hassan SHA, Kim SJ, Jung AY, Joo JH, Oh SE, et al. (2009) Biosorptive capacity of $\mathrm{Cd}$ (II) and $\mathrm{Cu}$ (II) by lyophilized cells of Pseudomonas stutzeri. J Gen Appl Microbiol 55: 27-34.

109. Öztürk A, Artan T, Ayar A (2004) Biosorption of nickel (II) and copper (II) ions from aqueous solution by Streptomyces coelicolor $A 3(2)$. Colloid Surface B 34: 105-111.

110. Wang J, Chen C (2009) Biosorbents for heavy metals removal and their future. Biotechnol adv 27: 195-226.

111. Han R, Li H, Li Y, Zhang J, Xiao H, et al. (2006) Biosorption of copper and lead ions by waste beer yeast. J hazard mater 137: 1569-1576.

112. Baillet F, Magnin JP, Cheruy A, Ozil P (1998) Chromium precipitation by the acidophilic bacterium Thiobacillus ferrooxidans. Biotechnol Lett 20: 95-99.

113. Farooq U, Kozinski JA, Khan MA, Athar M (2010) Biosorption of heavy metal ions using wheat based biosorbents-a review of the recent literature. Bioresour technol 101: 5043-5053.

114. Selatnia A, Boukazoula A, Kechid N, Bakhti MZ, Chergui A (2004) Biosorption of lead (II) from aqueous solution by a bacterial dead Streptomyces rimosus biomass. Biochem Eng J 19: 127-135.

115. Say R, Denizli A, Arıca MY (2001) Biosorption of cadmium (II), lead (II) and copper (II) with the filamentous fungus Phanerochaete chrysosporium. Bioresour technol 76: 67-70.

116. Yalçınkaya Y, Soysal L, Denizli A, Arıca MY, Bektaş S, et al. (2002) Biosorption of cadmium from aquatic systems by carboxymethylcellulose and immobilized Trametes versicolor. Hydrometallurgy 63: 31-40.

Citation: Tamiru M, Bekele G (2020) Various Absorbents and Parameters Affecting Removal of Water Hardness from Wastewater: 
117. Niu H, Xu XS, Wang JH, Volesky B (1993) Removal of lead from aqueous solutions by Penicillium biomass. Biotechnol Bioeng 42 785-787.

118. Das N, Vimala R, Karthika P (2008) Biosorption of heavy metals-An overview. 7: 159-169.

119. Lu Y, Wilkins E (1996) A mathematical model for the biosorption of copper on immobilized yeast in alginate. Environ Model Assess 1: 159-169.

120. Wang Y (2012) Optimization of cadmium, zinc and copper biosorption in an aqueous solution by Saccharomyces cerevisiae. Int J Chem 1: 1-13.

121. Sepehri A, Sarrafzadeh MH (2018) Effect of nitrifiers community on fouling mitigation and nitrification efficiency in a membrane bioreactor. Chem Eng Process 128: 10-18.

122. Guo Z, Tong YW (2013) The interactions between Chlorella vulgaris and algal symbiotic bacteria under photoautotrophic and photoheterotrophic conditions. Journal of Applied Phycology 26: 1483-1492.

123. Murray HH (1991) Overview- clay mineral applications. Appl Clay Sci 5: 379-395.

124. Wimpenny J (2016) Clay minerals. Encyclopedia of Geochemistry: A Comprehensive Reference Source on the Chemistry of the Earth.

125. Nakato T, Miyamoto $\mathrm{N}$ (2009) Liquid crystalline behavior and related properties of colloidal systems of inorganic oxide nanosheets. Materials (Basel) 2: 1734-1761.

126. Velde B (1995) Composition and mineralogy of clay minerals. Origin and Mineralogy of Clays: 8-42.

127. Gu S, Kang X, Wang L, Lichtfouse E, Wang C (2019) Clay mineral adsorbents for heavy metal removal from wastewater: a review. Environ Chem Lett 17: 629-654.

128. Dixon JB, Weed SB (1989) Minerals in soil environments, $2^{\text {nd }}$ Edition: Soil Science Society of America Inc. (SSSA).

129. Bhattacharyya KG, Gupta SS (2008) Adsorption of a few heavy metals on natural and modified kaolinite and montmorillonite: $A$ review. Adv Colloid Interface Sci 140: 114-131.

130. Renu, Agarwal M, Singh K (2017) Heavy metal removal from wastewater using various adsorbents: a review. J Water Reuse Desalination 7: 387-419.

131. Drever JI (1988) The geochemistry of natural waters. Prentice-Hal 437.

132. Milliken K (2005) Late diagenesis and mass transfer in sandstoneshale sequences. In: Mackenzie FT (eds). Sediments, Diagenesis and Sedimentary Rocks, Treatise on Geochemistry 7 Elsevier.

133. Sen T, Sarali M (2008) Adsorption of cadmium metal ion $\left(\mathrm{Cd}^{2+}\right)$ from its aqueous solution by aluminium oxide and kaolin: A kinetic and equilibrium study. J Environ Res Dev 3: 220-227.

134. Yavuz O, Altunkaynak Y, Güzel F (2003) Removal of copper, nickel, cobalt and manganese from aqueous solution by kaolinite. Water res 37: 948-952.

135. Bhattacharyya KG, Gupta SS (2008) Kaolinite and montmorillonite as adsorbents for $\mathrm{Fe}$ (III), $\mathrm{Co}$ (II) and $\mathrm{Ni}$ (II) in aqueous medium. Applied Clay Sci 41: 1-9.

136. Jiang $M-Q$, Jin X-Y, Lu X-Q, Chen Z-L (2010) Adsorption of Pb (II), Cd (II), Ni (II) and Cu (II) onto natural kaolinite clay. Desalination 252 33-39.
137. Shahmohammadi-Kalalagh $S$ (2011) Isotherm and kinetic studies on adsorption of $\mathrm{Pb}, \mathrm{Zn}$ and $\mathrm{Cu}$ by kaolinite. Caspian J Environ Sci 9 : 243-255.

138. Ozdes D, Duran C, Senturk HB (2011) Adsorptive removal of Cd (II) and $\mathrm{Pb}$ (II) ions from aqueous solutions by using Turkish illitic clay. J Environ Manage 92: 3082-3090.

139. Liu Z-r, Zhou S-q (2010) Adsorption of copper and nickel on $\mathrm{Na}$ bentonite. Process safety environ protect 88: 62-66.

140. Kubilay S, Gürkan R, Savran A, Şahan T (2007) Removal of Cu (II), Zn (II) and Co (II) ions from aqueous solutions by adsorption onto natural bentonite. Adsorption 13: 41-51.

141. Sathyanarayana B, Seshaiah K (2011) Kinetics and equilibrium studies on the sorption of manganese (II) and nickel (II) onto kaolinite and bentonite. J Chem 8 .

142. Oter O, Akcay H (2007) Use of natural clinoptilolite to improve water quality: sorption and selectivity studies of lead (II), copper (II), zinc (II), and nickel (II). Water Environ Res 79: 329-335.

143. Jitniyom K, Suddhiprakarn A, Kheoruenromne I (2012) Adsorption of lead, zinc, copper and cadmium of smectite. Proceedings of the $50^{\text {th }}$ Kasetsart University Annual Conference, Kasetsart University, Thailand.

144. Ketcha Mbadcam J, Dongmo S, Dinka'a Ndaghu D (2012) Kinetic and thermodynamic Studies of the Adsorption of $\mathrm{Ni}$ (II) ions from Aqueous solutions by Smectite Clay from Sagba-Cameroun. Inter J Cur Res 4: 162-167.

145. Olu-Owolabi $\mathrm{BI}$, Unuabonah El (2011) Adsorption of $\mathrm{Zn}^{2+}$ and $\mathrm{Cu}^{2+}$ onto sulphate and phosphate-modified bentonite. Applied Clay Sc 51: 170-173.

146. Smith J (1984) Definition of a zeolite. Zeolites 4: 309-310.

147. Ayele L, Perez-Periente j, Chebude Y, Diaz I (2015) Synthesis of zeolite A from Ethiopian kaolin. Microporous Mesoporous Materials 215: $29-36$

148. Moshoeshoe M, Nadiye-Tabbiruka MS, Obuseng V (2017) A review of the chemistry, structure, properties and applications of zeolites. Am J Mater Sci 7: 196-221.

149. ZhaoTeng $X$, ZhongLin L, JingHong M, Xiang B, YuHong K, et al. (2014) Effective removal of $\mathrm{Mg}^{2+}$ and $\mathrm{Ca}^{2+}$ ions by mesoporous LTA zeolite. Desalination 341: 10-18.

150. Von-Kiti E (2012) Synthesis of zeolites and their application to the desalination of seawater.

151. Parsons I, Deer WA, Howie RA, Zussman J (1992) An Introduction to the Rock-Forming Minerals, $2^{\text {nd }}$ Edition. London (Longman Scientific \& Technical). Mineralogical Magazine 56: 617-619.

152. Sherman JD (1999) Synthetic zeolites and other microporous oxide molecular sieves. Proceedings of the National Academy of Sciences 96: $3471-3478$

153. Roque-Malherbe R (2001) Handbook of Surfaces and Interfaces of Materials. Nalwa HS (eds) $1^{\text {st }}$ Edition, ,Academic Press, New York.

154. Roque-Malherbe R (2001) Dielectric methods of research on zeolites and related materials. Handbook of Surfaces and Interfaces of Materials, Elsevier. 509-531.

155. de Gennaro B (2019) Surface modification of zeolites for environmental applications, In Modified Clay and Zeolite Nanocomposite Materials. Elsevier. 57-85.

Citation: Tamiru M, Bekele G (2020) Various Absorbents and Parameters Affecting Removal of Water Hardness from Wastewater: 
156. Polat E, Karaca M, Demir H, Onus AN (2004) Use of Natural Zeolite (Clinoptilolite) in Agriculture. J Fruit Ornam Plant Res Special edition 12: 183-189.

157. Doumit P (2017) The production of zeolitic materials from sugar cane bagasse ash.

158. Wingenfelder U, Furrer G, Schulin R (2006) Sorption of antimonate by HDTMA-modified zeolite. Microporous Mesoporous Materials 95: 265-271.

159. Haggerty GM, Bowman RS (1994) Sorption of chromate and other inorganic anions by organo-zeolite. Environ Sci Technol 28: 452-458.

160. Yuna Z (2016) Review of the natural, modified, and synthetic zeolites for heavy metals removal from wastewater. Environ Engineer Sci 33: 443-454.

161. Flanigen EM (1991) Chapter 2 Zeolites and Molecular Sieves an Historical Perspective. Studies in surface science and catalysis. Elsevier 58: 13-34.

162. Król M (2020) Natural vs Synthetic Zeolites. MDPI 10: 622.

163. Prasad B, Maity S, Kumari S, Mortimer R (2012) Synthesis and Characterisation of Zeolite Prepared from Coal Ash by Hydrothermal Process. Environ Technol 33: 37-50.

164. Ahmaruzzaman M (2010) A review on the utilization of fly ash Progress in energy and combustion science. 36: 327-363.

165. Megawatia, Fardhyanti DS, Putri RDA, Fianti O, Simalango AF, et al. (2018) Synthesis of Silica Powder from Sugar Cane Bagasse Ash and Its Application as Adsorbent in Adsorptive-distillation of Ethanolwater Solution. MATEC Web of Conferences 237: 02002.

166. Wajima T, Kiguchi O, Sugawara K, Sugawara T (2009) Synthesis of Zeolite-A Using Silica from Rice Husk Ash. Journal of Chemical Engineering of Japan 42: s61-s66.

167. Menna Mohamed (2017) Zeolite Synthesis Characterisation and Application. SCRIBD.

168. Javadian H, Ghorbani F, Tayebi H, Asl HS (2015) Study of the adsorption of Cd (II) from aqueous solution using zeolite-based geopolymer, synthesized from coal fly ash; kinetic, isotherm and thermodynamic studies. Arabian Journal of Chemistry 8: 837-849.

169. de C Izidoro J, Fungaro DA, Abbott JE, Wang S (2013) Synthesis of zeolites $\mathrm{X}$ and $\mathrm{A}$ from fly ashes for cadmium and zinc removal from aqueous solutions in single and binary ion systems. Fuel 103: 827-834.

170. Franus W, Wdowin M, Franus M (2014) Synthesis and characterization of zeolites prepared from industrial fly ash. Environ Monit Assess 186: 5721-5729.

171. Wang H, Liu Y, Zeng G, Hu X, Hu X, et al. (2014) Grafting of $\beta$-cyclodextrin to magnetic graphene oxide via ethylenediamine and application for $\mathrm{Cr}(\mathrm{VI})$ removal. Carbohydr Polym 113: 166-173.

172. Liu H, Linag S, Gao J, Ngo HH, Guo W, et al. (2014) Enhancement of Cr (VI) removal by modifying activated carbon developed from Zizania caduciflora with tartaric acid during phosphoric acid activation. Chemical Engineering Journal 246: 168-174.

173. Ayrault S, Pape PL, Evrard O, Priadi CR, Quantin C, et al. (2014) Remanence of lead pollution in an urban river system: a multiscale temporal and spatial study in the Seine River basin, France. Environmental Science and Pollution Research 21: 4134-4148.

174. Siregar AS, Sulistyo I, Prayogo NA (2020) Heavy metal contamination in water, sediments and Planiliza subviridis tissue in the Donan River, Indonesia. Journal of Water and Land Development.
175. Lopresto CG, Mukherjee D, Zabala KAB, Calabro V, Curcio S, et al. (2018) Industrial Water Pollution and Treatment-Can Membranes be a Solution? Organic Pollutants in Wastewater I 295.

176. Yulianis M, Muhammad S (2017) Adsorption of copper ions using activated nano natural zeolite. Litbang Ind 7: 61-69.

177. Khaosomboon P, Khuanmar K, Weerayutsil P (2018) Synthesis of Zeolite-A and Zeolite-Y Using Silica Gel Waste as Silica Source and Modifying with Fe. International Journal of Engineering \& Technology 7: 1376-1379.

178. Moriarty P (2001) Nanostructured materials. Reports on Progress in Physics 64: 297.

179. Khan I, Saeed K, Khan I (2019) Nanoparticles: Properties, applications and toxicities. Arabian journal of chemistry 12: 908-931.

180. Rao GP, Lu C, Su F (2007) Sorption of divalent metal ions from aqueous solution by carbon nanotubes: a review. Separation and purification technology 58: 224-231.

181. Gopalakrishnan A, Krishnan R, Thangavei S, Vengopal G, Kim S (2015) Removal of heavy metal ions from pharma-effluents using graphene-oxide nanosorbents and study of their adsorption kinetics. Journal of Industrial and Engineering Chemistry 30: 14-19.

182. Ameen S (2020) Introductory Chapter: Prospects of Nanostructured Materials. Nanostructures.

183. Kroto HW, Heath JR, Brien SCO, Curl RF, Smalley RE (1985) C60: Buckminsterfullerene. Nature 318: 162-163.

184. Lucena R, Simonet BM, Cardenas S, Valcarcel M (2011) Potential of nanoparticles in sample preparation. Journal of Chromatography $A$ 1218: 620-637.

185. Zhang BT, Zheng X, Li HF, Lin JM (2013) Application of carbon-based nanomaterials in sample preparation: A review. Anal Chim Acta 784 1-17.

186. Novoselov KS, Falko VL, Colombo L, Gellert PR, Schwab MG, et al. (2012) A roadmap for graphene. Nature 490: 192-200.

187. Thangavel S, Venugopal G (2014) Understanding the adsorption property of graphene-oxide with different degrees of oxidation levels. Powder technology 257: 141-148.

188. Huang X, Yin Z, Wu S, Qi X, He Q, et al. (2011) Graphene based materials: synthesis, characterization, properties, and applications. Small 7: 1876-1902.

189. Zhao G, Li J, Ren X, Chen C, Wang X (2011) Few-layered graphene oxide nanosheets as superior sorbents for heavy metal ion pollution management. Environ Sci Technol 45: 10454-10462.

190. lijima S (1991) Helical microtubules of graphitic carbon. Nature 354: 56-58.

191. Wang X, Guo Y, Yang L, Han M, Zhao J, et al. (2012) Nanomaterials as sorbents to remove heavy metal ions in wastewater treatment. J Environ Anal Toxicol 2: 154-158.

192. Fernández-García M, Rodriguez JA (2007) Metal Oxide Nanoparticles. Brookhaven National Laboratory BNL-79479.

193. Alswata AA, Ahmad MB, Al-Hada NM, Kamari HM, Hussein MZ, et al. (2017) Preparation of zeolite/zinc oxide nanocomposites for toxic metals removal from water. Results Phys 7: 723-731.

194. Bootharaju MS, Pradeep T (2010) Uptake of toxic metal ions from water by naked and monolayer protected silver nanoparticles: an X-ray photoelectron spectroscopic investigation. J Phys Chem C 114: $8328-8336$.

Citation: Tamiru M, Bekele G (2020) Various Absorbents and Parameters Affecting Removal of Water Hardness from Wastewater: 
195. Ma X, Wang Y, Gao M, Xu H, Li G (2010) A novel strategy to prepare $\mathrm{ZnO} / \mathrm{PbS}$ heterostructured functional nanocomposite utilizing the surface adsorption property of $\mathrm{ZnO}$ nanosheets. Catal Today 158: 459-463.

196. Liang P, Shi T, Li J (2004) Nanometer-size titanium dioxide separation/ preconcentration and FAAS determination of trace $\mathrm{Zn}$ and $\mathrm{Cd}$ in water sample. Int J Environ An Ch 84: 315-321.

197. Chen Y-H, Li F-A (2010) Kinetic study on removal of copper(II) using goethite and hematite nano-photocatalysts. J Colloid Interface Sci 347: 277-281.

198. Tarasevich YI, Klimova GM (2001) Complex-forming adsorbents based on kaolinite, aluminium oxide and polyphosphates for the extraction and concentration of heavy metal ions from water solutions. Appl Clay Sci 19: 95-101.

199. Recillas S, Colón J, Casals E, González E, Puntes V, et al. (2010) Chromium $\mathrm{VI}$ adsorption on cerium oxide nanoparticles and morphology changes during the process. J Hazard Mater 184: 425431.

200. Pan B, Pan B, Zhang W, Lv L, Zhang Q, et al. (2009) Development of polymeric and polymer-based hybrid adsorbents for pollutants removal from waters. Chem Eng J 151: 19-29.

201. Posada Y (2009) Synthesis of silver nanoclusters on zeolite substrates. J Appl Phys 105: 126108-1-126108-3.

202. Mirjavadi ES, Tehrani RMA, Khadir A (2019) Effective adsorption of zinc on magnetic nanocomposite of $\mathrm{Fe}_{3} \mathrm{O}_{4}$ /zeolite/cellulose nanofibers: kinetic, equilibrium, and thermodynamic study. Environ Sci Pollut Res Int 26: 33478-33493.

203. Yuan X, Wang Y, Wang J, Zhoub C, Tang Q, et al. (2013) Calcined graphene/MgAl-layered double hydroxides for enhanced $\mathrm{Cr}(\mathrm{VI})$ removal. Chem Eng J 221: 204-213.

204. Fang F, Kong L, Huang J, Wu S, Zhang K, et al. (2014) Removal of cobalt ions from aqueous solution by an amination graphene oxide nanocomposite. J Hazard Mater 270: 1-10.

205. Jiao C, Xiong J, Tao J, Xu S, Zhang D, et al. (2016) Sodium alginate/ graphene oxide aerogel with enhanced strength-toughness and its heavy metal adsorption study. Int J Biolog Macromol 83: 133-141.

206. Chandra V, Park J, Chun Y, Lee JW, Hwang I, et al. (2010) Waterdispersible magnetite-reduced graphene oxide composites for arsenic removal. ACS Nano 4: 3979-3986.

207. Mollahosseini A, Khadir A, Saeidian J (2019) Core-shell polypyrrole/ $\mathrm{Fe}_{3} \mathrm{O}_{4}$ nanocomposite as sorbent for magnetic dispersive solidphase extraction of $\mathrm{Al}^{+3}$ ions from solutions: investigation of the operational parameters. J Water Process Eng 29: 100795.
208. Alswata AA, Ahmad MB, Al-Hada NM, Kamari HM, Hussein MZ, et al. (2017) Preparation of zeolite/zinc oxide nanocomposites for toxic metals removal from water. Results Phys 7: 723-731.

209. Mirjavadi ES, Tehrani RMA, Khadir A (2019) Effective adsorption of zinc on magnetic nanocomposite of Fe3O4/zeolite/cellulose nanofibers: kinetic, equilibrium, and thermodynamic study. Environ Sci Pollut Res Int 26: 33478-33493.

210. Walker GM, Hansen L, Hanna J-A, Allen SJ (2003) Kinetics of reactive dye adsorption onto dolomitic sorbents. Wat Res 37: 2081-2089.

211. Hui KS, Chao CYH, Kot SC (2005) Removal of mixed heavy metal ions in wastewater by zeolite $4 \mathrm{~A}$ and residual products from recycled coal fly ash. J Hazard Mater 127: 89-101.

212. Ji F, Li C, Tang B, Xua J, Lu G, et al. (2012) Preparation of cellulose acetate/zeolite composite fiber and its adsorption behavior for heavy metal ions in aqueous solution. Chem Eng J 209: 325-333.

213. Rodrigues DAS, Moura JM, Dotto GL, Cadaval TRS, Pinto LAA, et al. (2018) Preparation, characterization and dye adsorption/reuse of chitosan-vanadate films. J Polym Environ 26: 2917-2924.

214. Mahdavi M, Ahmad MB, Haron MJ, Gharayebi Y, Shameli K, et al. (2013) Fabrication and characterization of $\mathrm{SiO}_{2} /(3$-aminopropyl) triethoxysilane-coated magnetite nanoparticles for lead (II) remova from aqueous solution. J Inorg Organomet Polym Mater 23: 599607.

215. Rawajih Z, Nsour N (2008) Thermodynamic analysis of sorption isotherms of chromium ( $\mathrm{VI}$ ) anionic species on reed biomass. Chem Thermodyn 40: 846-851

216. Hao Y-M, Man C, Hu Z-B (2010) Effective removal of Cu (II) ions from aqueous solution by amino-functionalized magnetic nanoparticles. $J$ Hazard Mater 184: 392-399.

217. Mihajlović MT, Lazarević SS, Janković-Častvan IM, Kovač J, Jokić BM, et al. (2015) Kinetics, thermodynamics, and structural investigations on the removal of $\mathrm{Pb}^{2+}, \mathrm{Cd}^{2+}$, and $\mathrm{Zn}^{2+}$ from multicomponent solutions onto natural and Fe (III)-modified zeolites. Clean Technol Environ Pol 17: 407-419.

218. Alswata AA, Ahmad MB, Al-Hada NM, Kamari HM, Hussein MZ, et al. (2017) Preparation of zeolite/zinc oxide nanocomposites for toxic metals removal from water. Results Phys 7: 723-731.

219. Manyangadze M, Chikuruwo NHM, Narsaiah TB, Chakra CS, Radhakumari M, et al. (2020) Enhancing adsorption capacity of nano-adsorbents via surface modification: A review. S Afr J Chem Eng 31: 25-32. 